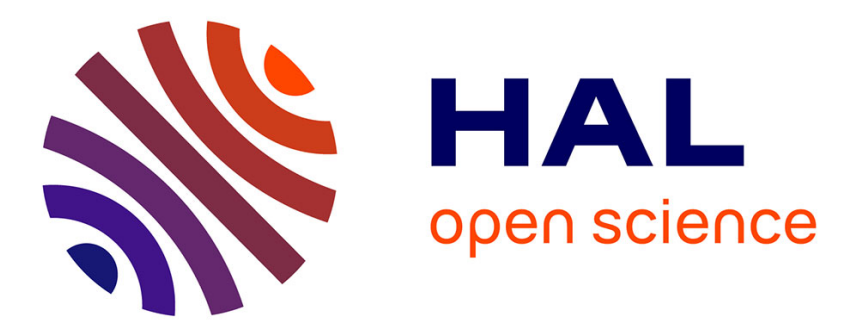

\title{
Fluid transfer into the wedge controlled by high-pressure hydrofracturing in the cold top-slab mantle
}

\author{
J. A. Padron-Navarta, Andrea Tommasi, Carlos J. Garrido, Vicente Lopez \\ Sanchez-Vizcaino, Maria Teresa Gomez-Pugnaire, Antonio Jabaloy, Alain \\ Vauchez
}

\section{To cite this version:}

J. A. Padron-Navarta, Andrea Tommasi, Carlos J. Garrido, Vicente Lopez Sanchez-Vizcaino, Maria Teresa Gomez-Pugnaire, et al.. Fluid transfer into the wedge controlled by high-pressure hydrofracturing in the cold top-slab mantle. Earth and Planetary Science Letters, 2010, 297 (1-2), pp.271-286. 10.1016/j.epsl.2010.06.029 . hal-00534035

\section{HAL Id: hal-00534035 \\ https://hal.science/hal-00534035}

Submitted on 4 Nov 2021

HAL is a multi-disciplinary open access archive for the deposit and dissemination of scientific research documents, whether they are published or not. The documents may come from teaching and research institutions in France or abroad, or from public or private research centers.
L'archive ouverte pluridisciplinaire HAL, est destinée au dépôt et à la diffusion de documents scientifiques de niveau recherche, publiés ou non, émanant des établissements d'enseignement et de recherche français ou étrangers, des laboratoires publics ou privés. 


\title{
Fluid transfer into the wedge controlled by high-pressure hydrofracturing in the cold top-slab mantle
}

\author{
José Alberto Padrón-Navarta ${ }^{\mathrm{a}, *}$, Andréa Tommasi ${ }^{\mathrm{b}}$, Carlos J. Garrido ${ }^{\mathrm{c}}$, Vicente López Sánchez-Vizcaíno ${ }^{\mathrm{d}}$, \\ María Teresa Gómez-Pugnaire ${ }^{\mathrm{a}, \mathrm{c}}$, Antonio Jabaloy ${ }^{\mathrm{e}}$, Alain Vauchez ${ }^{\mathrm{b}}$ \\ a Departamento de Mineralogía y Petrología, Universidad de Granada, Facultad de Ciencias, Avda Fuentenueva s/n, 18002 Granada, Spain \\ b Géosciences Montpellier, CNRS Er Université Montpellier 2, F-34095 Montpellier cedex 5, France \\ c Instituto Andaluz de Ciencias de la Tierra (IACT), CSIC E UGR, Facultad de Ciencias, 18002 Granada, Spain \\ ' Departamento de Geología, Universidad de Jaén (Unidad Asociada al CSIC-IACT Granada), Escuela Politécnica Superior, Alfonso X El Sabio 28,23700 Linares, Spain \\ e Departamento de Geodinámica, Universidad de Granada, 18002 Granada, Spain
}

Before attaining the mantle wedge, where they trigger partial melting, volatiles released from dehydration reactions in the slab have to migrate across a relatively cold $\left(<750^{\circ} \mathrm{C}\right)$, peridotite-layer above the incoming slab. In order to unravel the mechanisms allowing for this initial stage of fluid transport, we performed a detailed field and microstructural study of metamorphic prograde peridotites in the Cerro del Almirez ultramafic massif (Betic Cordillera, Spain), where evidences of one of the most important dehydration reactions in subduction zones, the high-pressure antigorite breakdown $\left(P=1.6-1.9 \mathrm{GPa}\right.$ and $\left.T \approx 680^{\circ} \mathrm{C}\right)$, can be mapped in the field. This reaction led to arborescent growth of centimeter-size olivine and orthopyroxene, producing a chlorite-harzburgite with a spinifex-like texture. Microstructural observations and crystal preferred orientations ( $\mathrm{CPO}$ ) mapping show no evidences of solid-state deformation during the prograde growth of olivine and orthopyroxene at the expenses of antigorite. However, a few tens to a hundred meters away from the reaction front, the metamorphic texture is partially obliterated by grain-size reduction in roughly planar conjugate zones, a few $\mathrm{mm}$ to meters wide. Grain size reduction zones (GSRZ) are characterized by (1) sharp contacts with undeformed spinifex-like texture domains, (2) important reduction of the olivine grain size $(60-250 \mu \mathrm{m})$, (3) olivine color change from brownish to colorless, (4) decrease in the modal amount of orthopyroxene, and (5) at the $\mathrm{mm}$ - to $\mathrm{cm}$-scale, irregular shapes and abrupt terminations. Field and microstructural observations exclude that relative displacement took place across these GSRZ. Changes in modal composition imply reactions with fluids undersaturated in silica. Analysis of olivine crystal-preferred orientations (CPO) in GSRZ shows patterns similar, but more dispersed, than those in neighboring spinifex-like domains. It also reveals $\mathrm{mm}$ - to $\mathrm{cm}$-scale discrete domains with rather homogeneous crystallographic orientations suggesting inheritance from the preexisting spinifex-like olivines in the host peridotite. Misorientation angles between neighboring grains in the GSRZ show peaks at $\sim 5-10^{\circ}$ and $\sim 20^{\circ}$, but rotations are not crystallographically controlled. Based on these observations, we rule out the formation of the GSRZ by dynamic recrystallization during dislocation creep and propose that they record brittle deformation (microcraking) of the spinifex-like chlorite-harzburgite, probably induced by hydrofracturing at high pressure and relative low temperature conditions $\left(680-710^{\circ} \mathrm{C}\right)$. High-pressure hydrofracturing can, thus, be invoked as an efficient mechanism for fluid flow across the cold top-slab mantle layer, hence allowing the slab-derived fluids to ingress in the wedge.

\section{Introduction}

Transfer of fluids from the subducting slab to the mantle wedge is an essential process in subduction dynamics, as it controls the onset of the partial melting process and, hence, the location and the chemical

\footnotetext{
* Corresponding author. Tel.: +34 958243358; fax: +34 958243368.

E-mail address: padron@ugr.es (J.A. Padrón-Navarta).
}

characteristics of the arc magmatism. Fluids release and motion from different parts of the subducting slab have also been proposed as one of the possible explanations for seismic tremor (e.g., Brown et al., 2005). Moreover, hydration-induced rheological weakening in the mantle wedge (Mackwell et al., 1985, Mei et al., 2002, Arcay et al., 2005) has been considered to change the subduction dynamics, producing extensive thinning of the upper plate (Arcay et al., 2006) or development of cold diapirs in the wedge (Gerya and Yuen, 2003). Furthermore, the release of fluids from the downgoing slab has been 
recently suggested as one of the driving forces controlling the style of subduction itself (Gerya et al., 2008). Migration of fluids produced by devolatilization reactions is thus a fundamental ingredient of the subduction machinery.

The mechanisms allowing the extraction of aqueous fluids from the slab and cold supra-slab mantle, where devolatilization reactions take place, are however still a matter of debate. Estimated dehydration fluxes (e.g., Hacker, 2008) depart significantly from the low fluid-rock interaction and limited fluid flow proposed at high- $P$ low- $T$ conditions in some fossil subduction zone suites based on stable isotope systematics and petrologic constrains (e.g., Ague, 2003, Hermann et al., 2006 and references therein). This discrepancy points to channeling of fluids into high permeability pathways, such as fractures or lithological contacts.

The dehydration of serpentinite (hydrated peridotite) through a series of discontinuous reactions is the process that potentially produces the largest amounts of fluids at high pressure conditions below the magmatic arc (Ulmer and Trommsdorff, 1995; Scambelluri et al., 1995; Schmidt and Poli, 1998; Scambelluri and Philippot, 2001; Padrón-Navarta et al., 2010). At pressures 1.5-5.5 GPa (depths of $\sim 45-$ $200 \mathrm{~km}$ ), this reaction produces chlorite-harzburgite in both the downgoing slab mantle and in the cold mantle wedge above the slab that was hydrated in earlier stages of subduction (Fig. 1) (Hacker et al.,
2003; Garrido et al., 2005). Fluids released from the slab and wedge serpentinite dehydration between 50 and $150 \mathrm{~km}$ depth certainly have to cross the cold $\left(680-750{ }^{\circ} \mathrm{C}\right), 5-10 \mathrm{~km}$ thick layer of chloriteharzburgite (Fig. 1) before attaining the hotter inner parts of the mantle wedge, where ductile deformation and fluid-rock reactions enhance the permeability and allow porous flow (e.g., Stevenson, 1989; Kelemen and Dick, 1995; Rosenberg and Handy, 2000; Holtzman et al., 2003; Takei, 2005; Le Roux et al., 2008; Soustelle et al., 2010). Nevertheless, the processes allowing transport of the dehydration-related fluids from the downgoing slab across the highviscosity (>10 22 Pa s, e.g. Gerya and Yuen, 2003), low permeability $\left(10^{-20}-10^{-23} \mathrm{~m}^{2}\right.$, e.g. Ague, 2003) chlorite-harzburgite layer have not been investigated so far, despite their implications for the fluid chemical signature and for the mechanical behavior of the slab-mantle interface.

In this paper we present a combined field and microstructural study of chlorite-harzburgite from the km-scale Cerro del Almirez ultramafic massif (Betic Cordillera, SE Spain) where the antigorite-out isograd produced by high-pressure serpentinite dehydration, the most important devolatilization reaction in subduction zones, can be mapped at the outcrop scale (Trommsdorff et al., 1998; Garrido et al., 2005; Padrón-Navarta et al., 2008). Analysis of the microstructures, crystal preferred orientations, and compositional changes in localized,

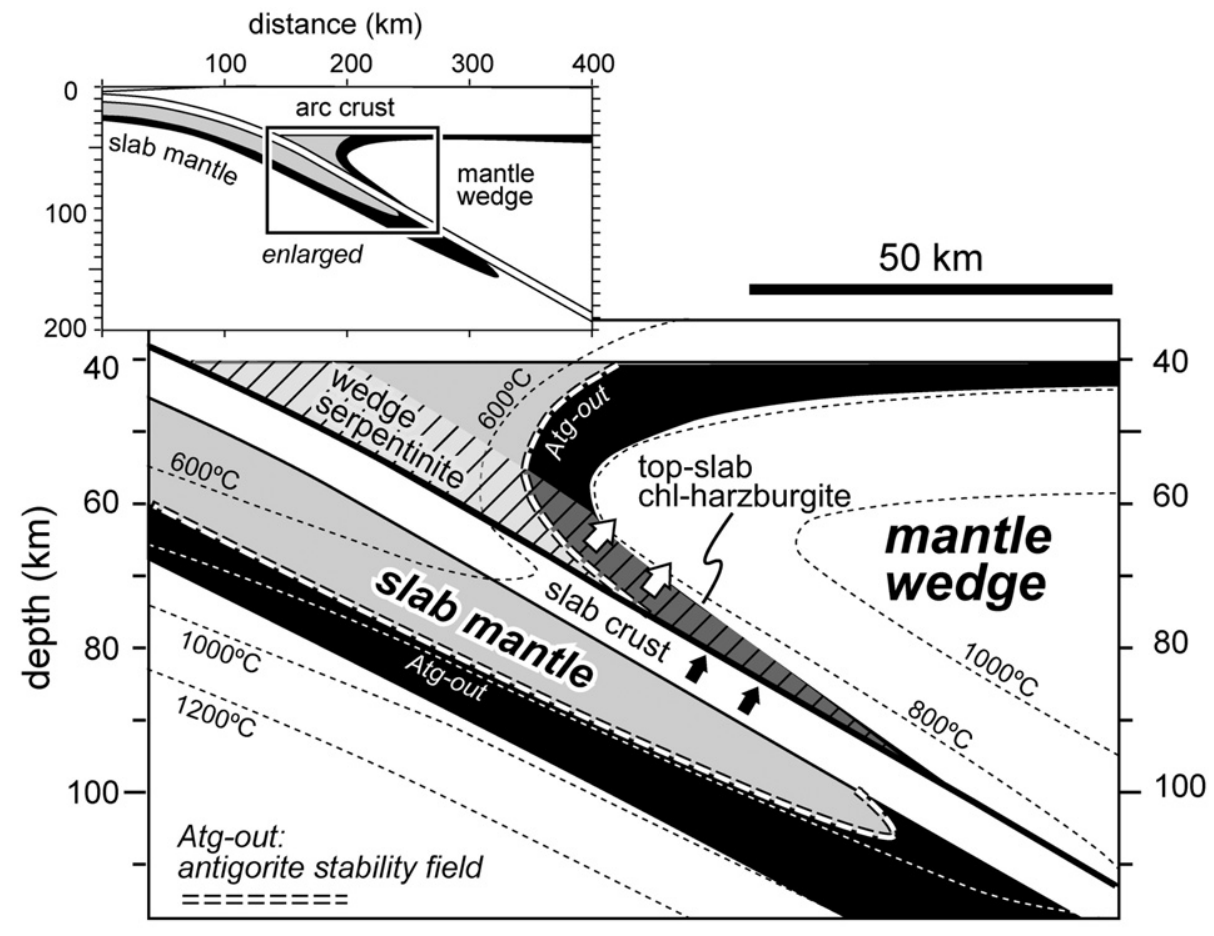

Hydrated ultramafic assemblages
\begin{tabular}{|ll|}
\hline $\begin{array}{l}\text { Theoretical stability fields } \\
\text { (after Hacker et al. 2003) }\end{array}$ & $\begin{array}{l}\text { Numerical model predictions } \\
\text { (after Gerya and Yuen 2003) }\end{array}$ \\
\hline $\begin{array}{l}\text { serpentinite } \\
\text { chl-harzburgite }\end{array}$ & $\begin{array}{l}\text { only from slab } \\
\text { dehydration }\end{array}$ \\
\hline $\begin{array}{l}\text { Fluid flow direction: } \\
\text { mainly from wedge } \\
\text { serpentinite dehydration }\end{array}$
\end{tabular}

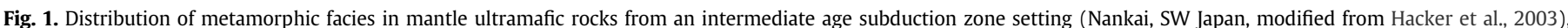

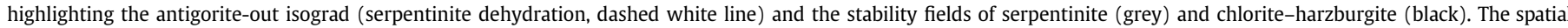

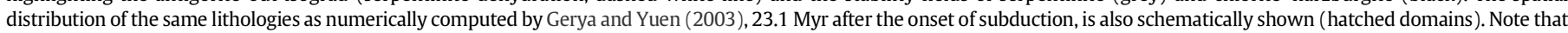

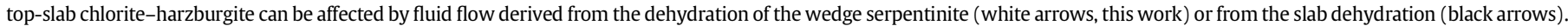


grain-size reduction bands crosscutting the prograde chloriteharzburgite suggest that brittle deformation took place under highpressure conditions, probably owing to hydrofracturing. We discuss the connection between this deformation and the transport of hydrous fluids produced at the antigorite dehydration front towards the mantle wedge and the potential implications of this process in subduction settings.

\section{The Cerro del Almirez ultramafic massif (Betic Cordillera, SE Spain)}

The Cerro del Almirez ultramafic massif is the largest $\left(\sim 2.3 \mathrm{~km}^{2}\right)$ of several small and discontinuous ultramafic bodies intercalated with metapelites, marbles and locally with orthogneisses, in the upper part of the Nevado-Filábride Complex, the lowermost unit of the Internal Zones of the Betic Cordillera (Southern Spain, Fig. 2a and b). The latter is part of the Betic-Rifean orogenic system (or peri-Alborán orogenic system), which is the westernmost segment of the Alpine belt in Europe.

The Cerro del Almirez massif is essentially composed of two rock types: foliated antigorite serpentinite in the present-day topographically upper half of this massif and more massive chlorite-harzburgite in the lower part (Figs. 2c and 4, Trommsdorff et al., 1998). Three smaller chlorite-harzburgite bodies, enclosed in metasediments, to the west of the Cerro del Almirez complete the sequence (Fig. 2c). Detailed petrographic and mineral chemistry studies, as well as thermodynamic calculations, lead Trommsdorff et al. (1998) to interpret the chlorite-harzburgite as a result of the high-pressure dehydration of the antigorite serpentinite during the Alpine metamorphism of the Nevado-Filábride Complex. This event occurred during the Middle Miocene, as revealed by SHRIMP U-Pb zircon ages of $15.0 \pm 0.6 \mathrm{Ma}$ in a meta-clinopyroxenite just outside the antigoriteout isograd (López Sánchez-Vizcaíno et al., 2001). Experiments (Padrón-Navarta et al., 2010) further constrain the maximum stability of antigorite $\left(680^{\circ} \mathrm{C}\right.$ at $\left.1.9 \mathrm{GPa}\right)$ and the peak metamorphic conditions of the chlorite-harzburgite to $680-710^{\circ} \mathrm{C}$ and $1.6-1.9 \mathrm{GPa}$. These $P T$ conditions are equivalent to those prevailing in the colder part of the mantle wedge in most subduction settings (cf. isotherms from Hacker et al., 2003 and Gerya and Yuen, 2003 models shown in Fig. 1). Therefore, the Cerro del Almirez ultramafic massif can be used as a proxy for this setting even though its actual position during subduction cannot be determined with precision due to the later tectonic evolution of the Nevado-Filabride Complex (Martínez-Martínez et al., 2002; see also Guillot et al., 2009 for a comprehensive discussion on the exhumation of high-pressure rocks during subduction).

One of the most striking features of the prograde chloriteharzburgite is its spinifex-like texture (Fig. 3a, Trommsdorff et al., 1998), owing to growth of large arborescent olivine crystals (up to $10 \mathrm{~cm}$ in length) in a matrix composed of radial aggregates of acicular orthopyroxene crystals (50-100 $\mu \mathrm{m}$ wide and $0.5-2 \mathrm{~mm}$ long), long chlorite flakes $(<1 \mathrm{~mm})$, aggregates of magnetite, and rare idiomorphic tremolite. Although very strong shape preferred orientations exist locally, there is not a general orientation pattern of the spinifex texture at the scale of the massif. The grain size and the preferred orientation of olivine and orthopyroxene crystals in the spinifex-like chlorite-harzburgite vary at the centimeter to meter scale. Strong shape preferred orientation of olivine crystals producing a typical fishtail texture (Fig. 3a) is usually observed in rocks with large and highly anisomorphic olivine crystals (up to $10 \mathrm{~cm}$ in length and aspect ratios of 50:1), whereas more radial/arborescent or even randomly oriented
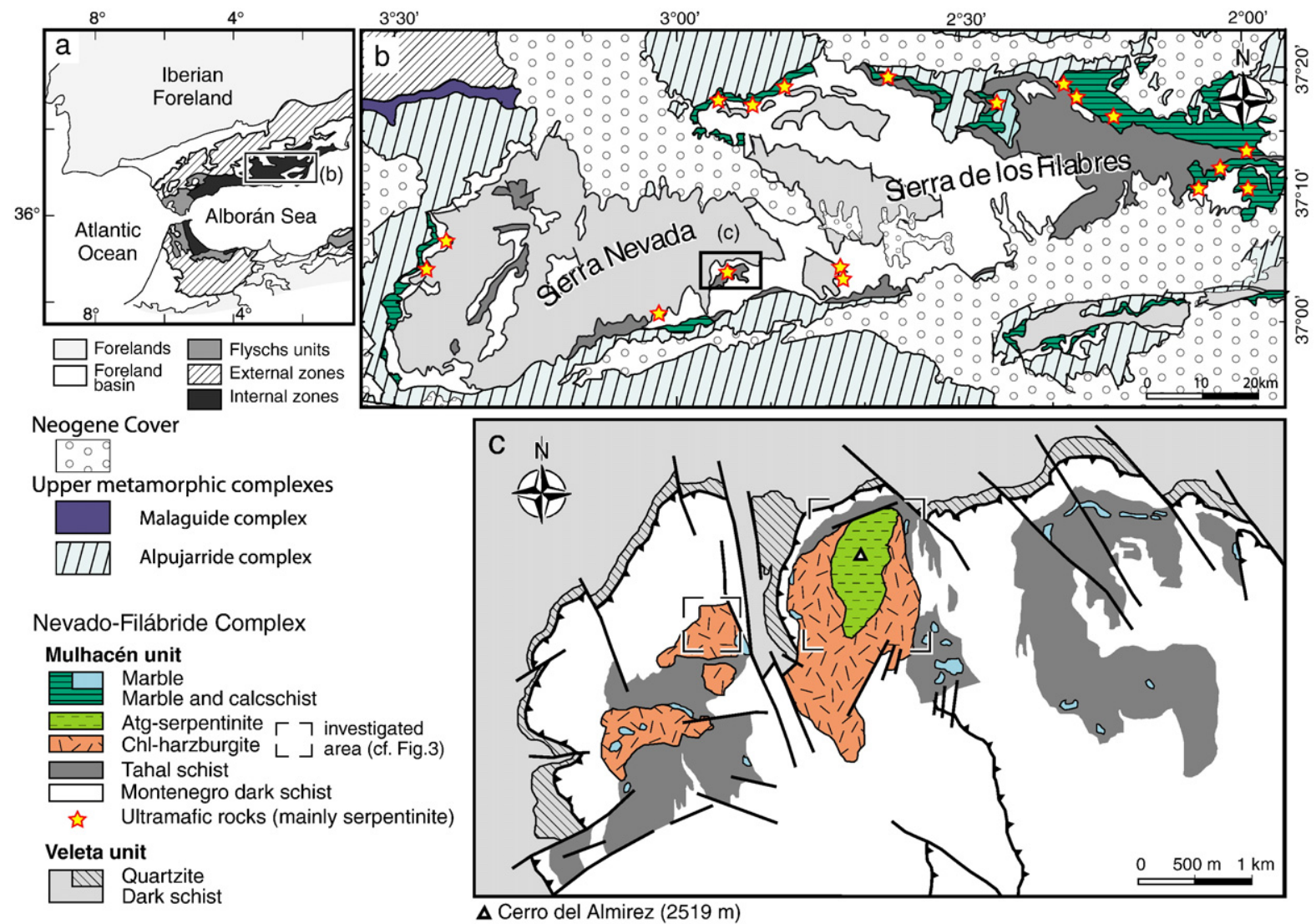

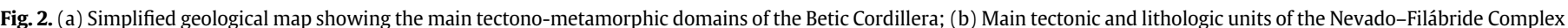

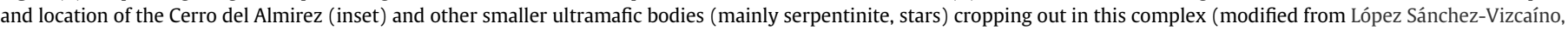

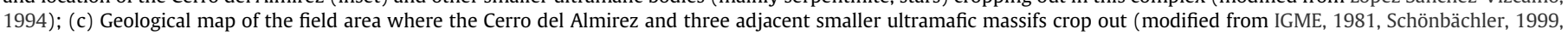
Hürlimann, 1999 and based on own observations). 

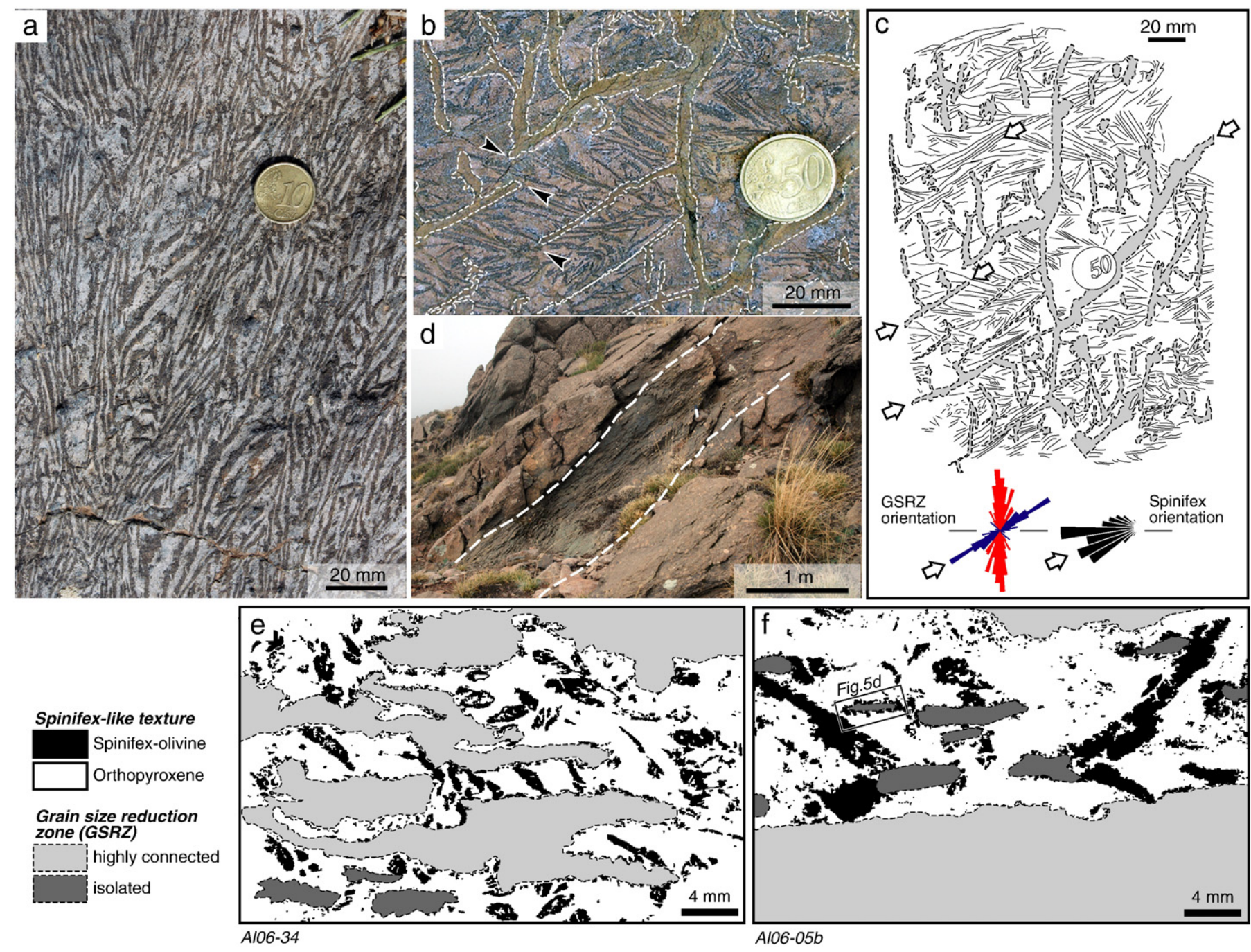

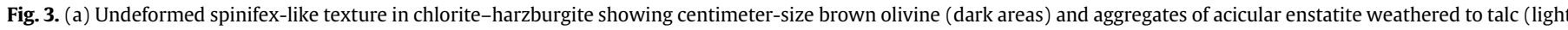

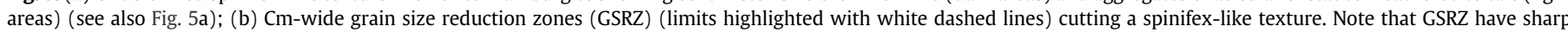

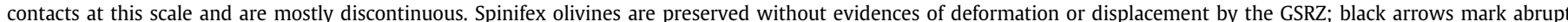

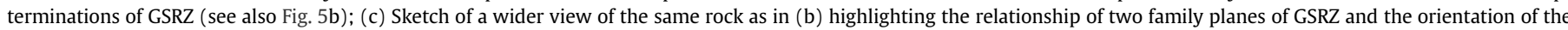

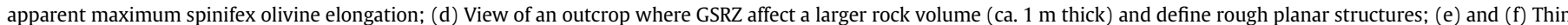

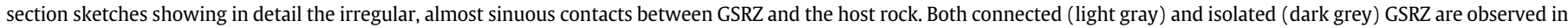
these two samples.

textures tend to correspond with smaller grain size $(5-10 \mathrm{~mm})$ and lower aspect ratio $(\sim 6: 1)$ olivine crystals. Moreover, not every chlorite-harzburgite outcrop displays a spinifex-like texture; chlorite-harzburgite characterized by coarse granular olivine (granofels texture) occurs intercalated with the spinifex-like one at the meter to tens of meters scale over the entire massif. The ol:opx modal proportion is similar $(\sim 1: 1)$ in both textures.

The prograde chlorite-harzburgite is locally transected by zones where important grain size reduction (GSR) of the olivine crystals occurs. In the present paper we study these structures that overprint both spinifex-like and granofels primary metamorphic textures. We focus on those developed at the expenses of the spinifex-like texture, because they allow for a better characterization of the changes relative to the original texture.

\section{Macro- and meso-scale observations}

At the outcrop and thin section scales, grain size reduction zones (GSRZ) are characterized by a conspicuous change in olivine color (Figs. $3 \mathrm{~b}$ and $5 \mathrm{~b}$ ). Spinifex-like olivine is brown due to the large amount of solid and fluid inclusions (Trommsdorff et al., 1998), while fine-grained olivine in the GSRZ is pale green and lacks impurities at submicroscopic scale.

GSR usually occurs in irregular bands with roughly planar shapes that are commonly a few $\mathrm{mm}$ to several $\mathrm{cm}$ wide and $\mathrm{cm}$ to $\mathrm{m}$ in length. More rarely, it occurs in small irregular pockets a few $\mathrm{mm}$ to $\mathrm{cm}$ wide (Fig. 3b and c). The abundance of GSRZ and the spacing between them are highly variable across the massif. In the Cerro del Almirez largest ultramafic body, GSR occurs essentially in small $\left(\mathrm{mm}^{3}\right.$ to $\left.\mathrm{cm}^{3}\right)$ volumes of the chlorite-harzburgite. In the smaller chlorite-harzburgite massif to the west of the main body (Figs. 2c and 4b), GSR affects larger volumes $\left(\mathrm{cm}^{3}\right.$ to $\left.\mathrm{m}^{3}\right)$ of the chlorite-harzburgite. In these areas, GSR occurs as closely-spaced $(2-3 \mathrm{~cm}$ apart) bands subparallel to each other that show sharp contacts with the host spinifex-like harzburgite.

Careful observation of mm- to cm-wide GSRZ at the outcrop scale, using spinifex-like olivine as strain markers (arrows in Fig. 3b), reveals no relative displacement (shearing extension, or opening) associated with the grain size reduction process. Analysis of the orientation of these small GSRZ and of the trace of the maximum elongation of the spinifex-like olivine in the outcrop (see also Fig. 3b 


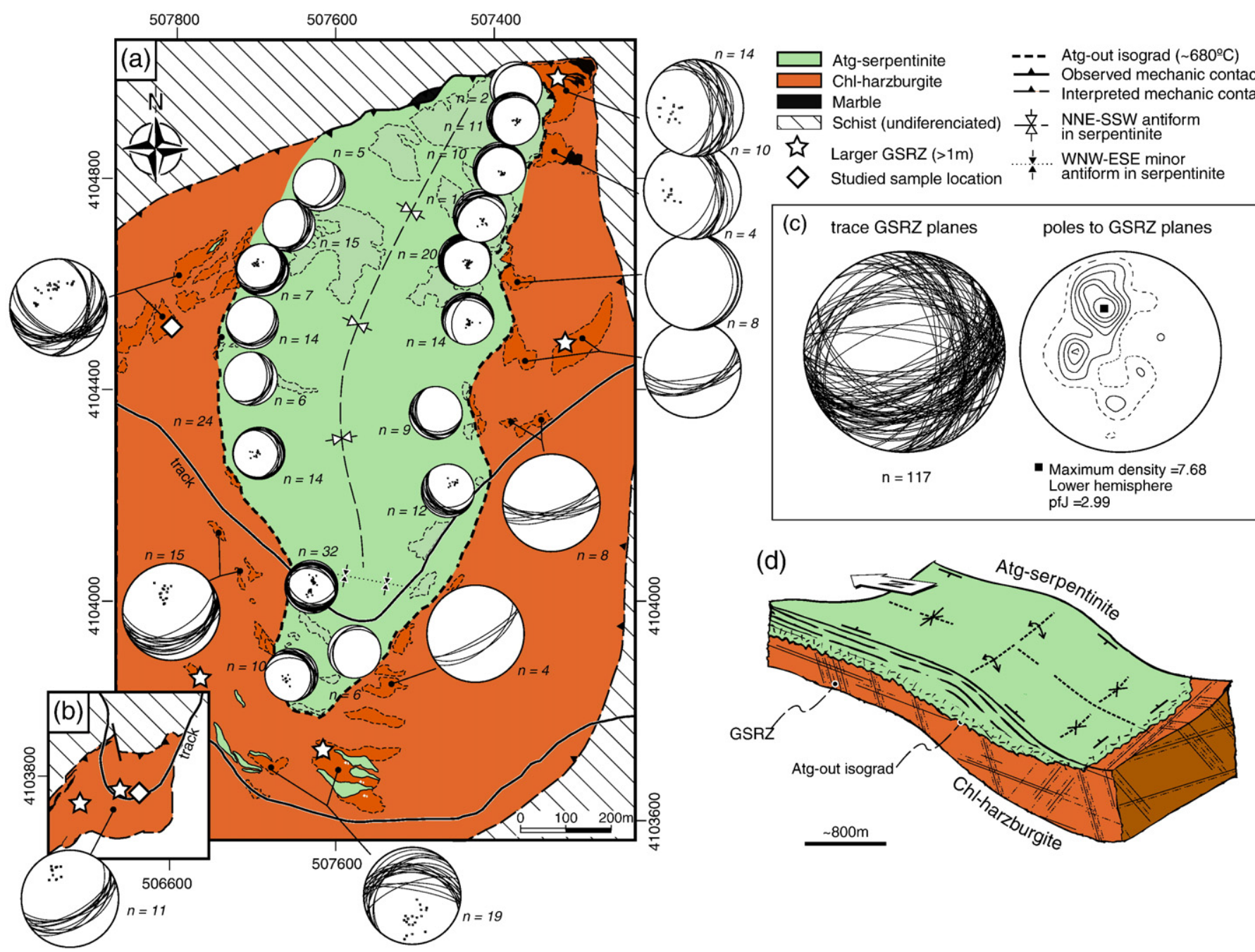

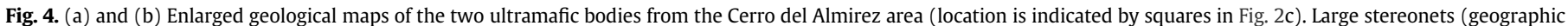

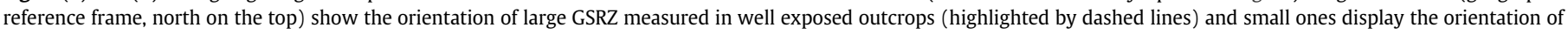

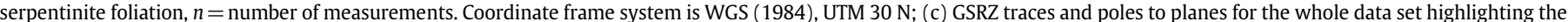

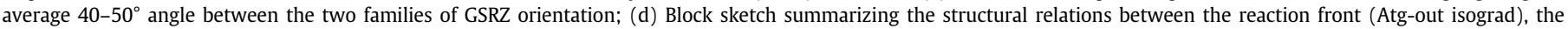
serpentinite foliation, and GSRZ in the present-day configuration of Cerro del Almirez. Note that the orientation of the GSRZ cut the antigorite-out isograd at variable angles.

and c) highlights a non-isotropic orientation pattern, characterized by two families of GSR planes intersecting at high angles $\left(\sim 60^{\circ}\right)$. The latter show no apparent clear relationship to the dominant spinifex olivine orientation (horizontal in Fig. 3c). However, a closer scrutiny shows that one of the two GSRZ orientations follows a locally welldeveloped shape preferred orientation of the spinifex olivine (white arrows in Fig. 3c).

At thin section scale, although a roughly planar structure is still observed, small GSRZ show more irregular, lobate shapes, but still have sharp limits (Fig. 3e and f). They are usually interconnected (light grey domains in Fig. 3e and f). However, recrystallization of single spinifex-olivine crystals is also observed producing isolated GSR pockets in an otherwise pristine spinifex-like texture (dark grey domains in Fig. 3e and f, see also Fig. 5d). Similarly to the outcrop scale, analysis of the spinifex structure on both sides of a GSRZ shows no relative displacement across it.

When the GSR affects larger rocks volumes, one orientation tends to dominate with respect to the other, resulting in thick (typically $50 \mathrm{~cm}-1 \mathrm{~m}$ ), usually meter-spaced ( $2 \mathrm{~m}$ or more), dark green, planar zones (Fig. 3d). Close to them, cm-scale incipient GSRZ can also be found. Neither olivine stretching nor magnetite lineation were observed in these thicker bands, pointing also to lack of displacement across them. The contact with the host spinifex-textured harzburgite is as sharp as in the mm- to cm-scale GSRZ (Fig. 3b and c). The distribution of these wide GSRZ is heterogeneous at the scale of the massif (stars in Fig. 4a). They occur close to the antigorite-out reaction front in the eastern part of the main ultramafic body, but also further away from it (Fig. 4a), as well as in the smaller ultramafic body located to the west (Fig. 4b).

Fig. 4a and b (large stereonets) show the measured orientation of the GSRZ bands in well-exposed outcrops. For reference, the serpentinite foliation, marked by the orientation of antigorite, is also shown (small stereonets in Fig. 4a). This shallowly dipping foliation $\left(20-30^{\circ}\right)$ defines an open NNE-SSW trending synclinal. Minor, WNWESE trending folds with rare crenulation cleavage are superimposed. Large GSRZ have clearly more steeply-dipping orientations (30-60 $0^{\circ}$. As for the mm- to cm-wide GSRZ (Fig. $3 \mathrm{~b}$ and c), analysis of the orientation data for all tens of $\mathrm{cm}$ to $\mathrm{m}$-wide GRSZ show a predominance of two conjugated planes at $\mathrm{ca} .55^{\circ}$ to each other, oriented N-S and ENE-WSW in average (Fig. 4c). Only the larger bands that define a rough planar fabric are plotted. However, another orientation, at $\sim 40-50^{\circ}$ from the main one (Fig. 4 a,b and c), occurs systematically in most outcrops. The three-dimensional block in Fig. $4 \mathrm{~d}$ schematically depicts the relative orientation of the structure of 

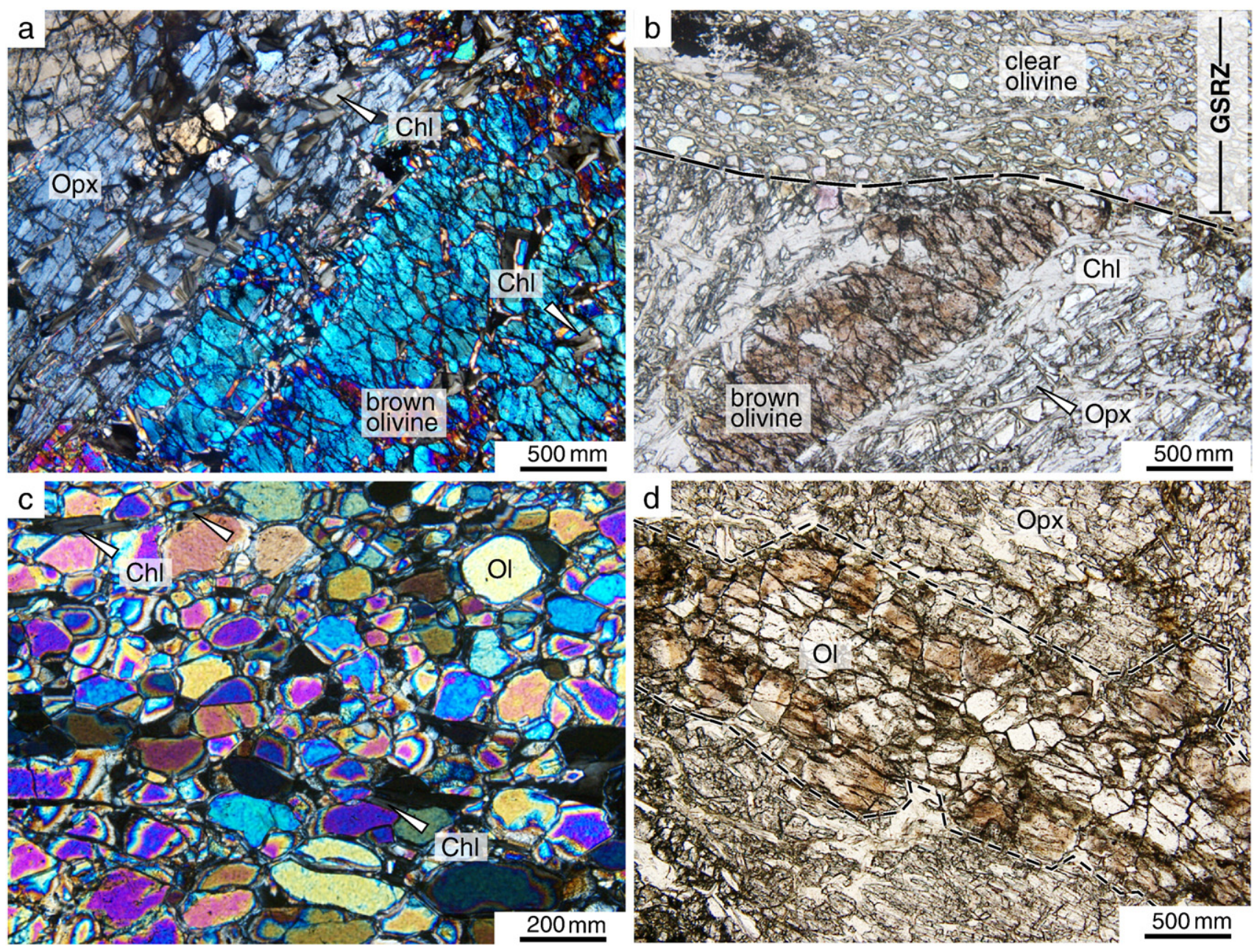

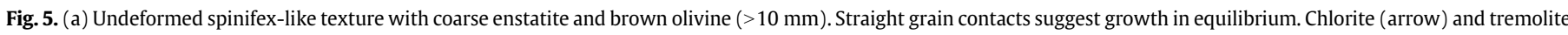

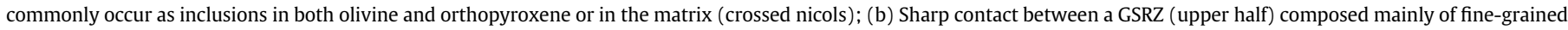

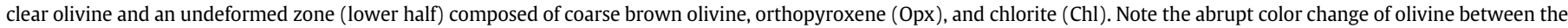

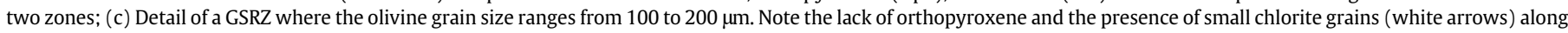

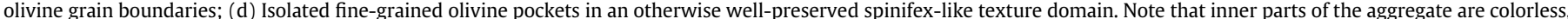

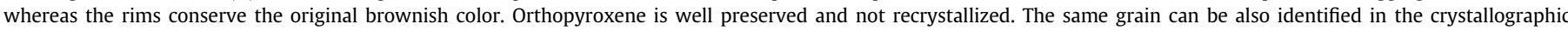
orientation map in Fig. 8d (the upper left isolated area). This and other isolated domains are closely related with a larger GSRZ in the lower part (cf. Fig. 8d).

antigorite-serpentinite, of the GSRZ in chlorite-harzburgite, and of the atg-out isograd in Cerro del Almirez main body. Most GSRZ (especially in the eastern and southern areas of the body) are clearly oblique to both the atg-out isograd and the foliation in atg-serpentinite.

\section{Microstructures}

\subsection{Spinifex-like texture}

Olivine in the spinifex-like texture is very coarse-grained (typically from $5 \mathrm{~mm}$ to up to $10 \mathrm{~cm}$ in length) and commonly encloses randomly oriented chlorite flakes (200-400 $\mu \mathrm{m}$, Fig. 5a). Spinifex olivine crystals are straight or, more commonly, slightly curved (sheath shapes). Grain boundaries are straight and commonly underlined by chlorite flakes. Spinifex olivine has a typical brownish pleochroism and is crowded with Fe-Cr-Ti-oxides, fluid inclusions (Scambelluri et al., 2001), and silicarich mineral inclusions (orthopyroxene and talc) parallel to (100) olivine planes (Ruiz Cruz et al., 1999). Microscopic lamellae of titanclinohumite parallel to (001) have been also reported (López SánchezVizcaíno et al., 2005). Orthopyroxene occurs in fan-like aggregates (up to $8 \mathrm{~cm}$ wide) composed of fine acicular crystals with similar crystallographic orientations (200-300 $\mu \mathrm{m}$ in length) and randomlyoriented chlorite flakes (Fig. 5a).

\subsection{Grain size reduction zones (GSRZ)}

At thin section scale (Fig. 5b and c), GSRZ are easily distinguished by (1) a reduction of the olivine grain size from mm-scale to $60-$ $250 \mu \mathrm{m}$ (grain sizes are estimated from grain areas in EBSD maps, which range from $15,000-26,000 \mu \mathrm{m}^{2}$, Table 1) and (2) an abrupt change in color of olivine from brownish in the spinifex-like domains to colorless in the recrystallized domains due to a lower content of inclusions (Fig. 5b). GSRZ have very sharp contacts with undeformed spinifex-like texture domains (Figs. 3e, f, and 5b). They are mostly composed of olivine, chlorite, magnetite, and minor tremolite (Fig. 5c). Olivine is equigranular with 5-6 faceted polygonal shapes (Fig. 5c), resulting in a well-developed granoblastic texture. Olivine crystals are deformation-free, without subgrains or wavy extinction, and free of inclusions. Grain boundaries are usually masked by lowtemperature serpentine due to late retrograde reactions. Chlorite flakes are small (100-150 $\mu \mathrm{m}$ in length, Fig. $5 \mathrm{c}$ ) and locally tend to align parallel to the elongation of the GSRZ. Orthopyroxene is also observed locally in GSRZ, forming isolated aggregates with irregular, 
Table 1

Proportion of grain size reduction zones (GSRZ), Opx:Ol modal ratio and average grain size in the investigated samples.

\begin{tabular}{|c|c|c|c|c|c|c|}
\hline \multirow[t]{2}{*}{ Sample } & \multirow[t]{2}{*}{ \% GSRZ } & \multicolumn{2}{|c|}{ Opx:Ol modal ratio } & \multicolumn{3}{|c|}{$\begin{array}{l}\text { Average olivine grain size } \\
\left(\mu \mathrm{m}^{2}\right)\end{array}$} \\
\hline & & $\begin{array}{l}\text { Spinifex-like } \\
\text { texture }\end{array}$ & GSRZ & $\begin{array}{l}\text { Spinifex-like } \\
\text { texture }\end{array}$ & $\begin{array}{l}\text { Number of } \\
\text { grains }\end{array}$ & GSRZ \\
\hline Al06-42 & 2 & 1.00 & - & $3,400,044$ & 65 & - \\
\hline Al06-05a & 36 & 1.03 & 0.14 & 684,653 & 38 & 15,100 \\
\hline Al06-34 & 38 & 1.16 & 0.17 & $1,845,159$ & 37 & 26,471 \\
\hline Al06-05b & 39 & 1.01 & 0.15 & $4,637,244$ & 14 & 25,481 \\
\hline Al06-35 & 46 & 1.22 & 0.10 & $1,024,691$ & 18 & 25,272 \\
\hline Al07-07 & 100 & - & 0.30 & - & - & 15,847 \\
\hline
\end{tabular}

a Calculated with CHANNEL 5 software package.

highly lobate shapes, but its proportion is much lower than in the spinifex-like texture domains (Table 1 ). Scarce orthopyroxene aggregates in GSRZ are acicular with fan-like distribution in the same way as those observed in the spinifex-like texture domains. Talc locally replaces orthopyroxene due to late retrograde reactions.

Recrystallization of isolated single spinifex olivine (Fig. 5d), outside the main GSRZ, also occurs (see also Fig. 3e and f). In these cases, the grain size reduction is less severe $(300-400 \mu \mathrm{m})$ and both the external shape of the original spinifex olivine crystal and its brownish color, in particular at the rims, are preserved. The misorientation between the recrystallized fragments derived from a single former spinifex olivine is weak, as indicated by the preservation of similar polarization colors and extinction angles. Orthopyroxene aggregates enclosing these isolated GSR olivine grains are not recrystallized. Furthermore, these isolated recrystallized domains within an otherwise undeformed spinifex-like harzburgite are less retrograded and late serpentine along olivine grain boundaries is lacking (Fig. 5d).

\subsection{Dislocations}

We used the decoration technique (Kohlstedt et al., 1976) to investigate the dislocation density and arrangement in samples where both the spinifex-like texture and GSRZ were present. This method consists in annealing a polished sample slab during $30 \mathrm{~min}$ in air at $900{ }^{\circ} \mathrm{C}$ (oxidizing conditions). A standard $30-\mu \mathrm{m}$ thin section is prepared with the previously polished face in contact with the glass slide. Observations were made using an optical microscope in planepolarized light (Fig. 6).

The strong oxidation of the spinifex-like olivine usually prevents a clear observation of its internal structure. When observations were possible, spinifex-like olivine contains closely-spaced inclusions preferentially arranged in two crystallographic directions. These crystallographically controlled inclusion trails probably correspond to the magnetite, Cr-bearing spinel, ilmenite, and other Ti-rich solid phase inclusions observed by transmission electron microscopy (Ruiz Cruz et al., 1999). Part of these inclusions (the titanium-bearing ones) were interpreted by López Sánchez-Vizcaíno et al. (2005) as products of destabilization of lamellar intergrowths of titano-clinohumite. Dislocations are very rarely observed in these crystals. Where present, they tend to be normal to the grain boundaries.

Olivine crystals in the GSRZ have dislocations, but their density is extremely low. Most crystals show large volumes completely devoid of dislocations (Fig. 6a). The most common feature, displayed by the majority of olivine crystals in GSRZ, are rather straight dislocation lines concentrated at the crystal rims and running normal to the polygonal faces of the crystal (Fig. 6b). Some dislocations are also observed around solid-phase inclusions. Finally, a few isolated crystals within GSRZ display a low density of polygonal dislocation loops (Fig. 6c), suggesting only incipient plasticity. Subgrain boundaries were never observed.
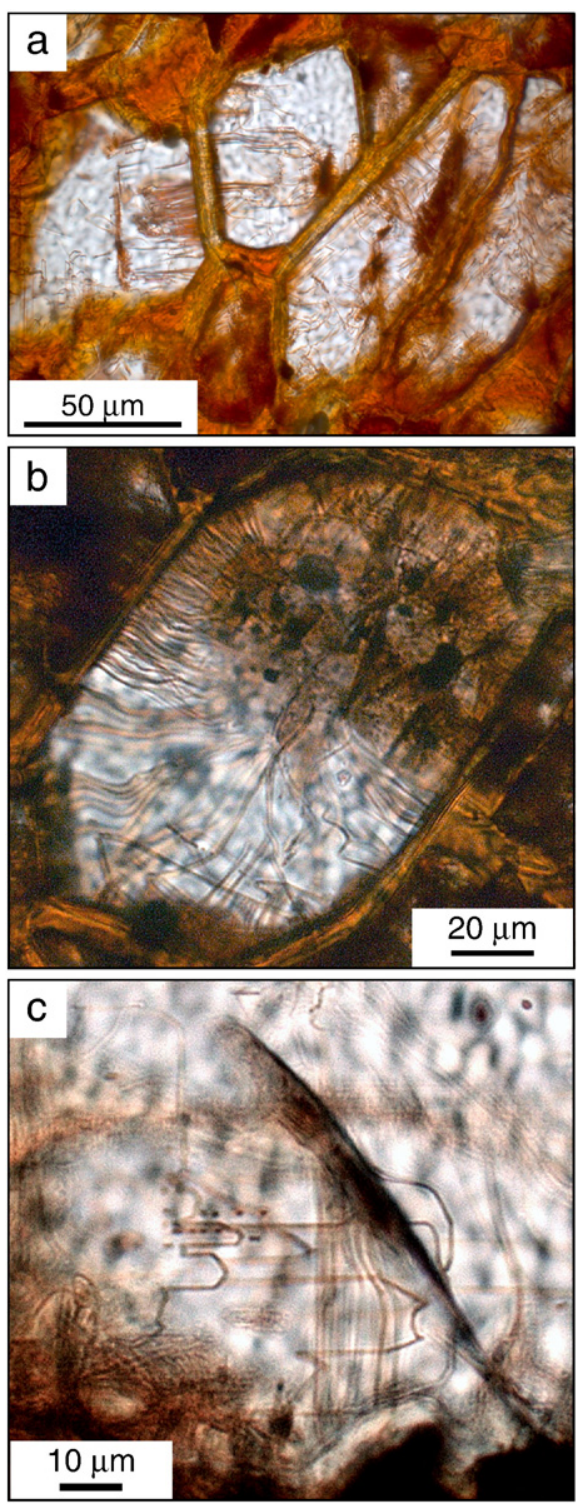

Fig. 6. Examples of decorated dislocations in olivine from GSRZ. Different observation scales showing: (a) the general low dislocation density (sample Al06-05b); (b) common radial dislocations normal to the crystals polygonal faces (sample Al06-05a); and (c) rare dislocations in glide morphologies in an olivine core (sample Al06-05b).

\section{CPO in the grain-size reduction zones}

\subsection{Sample selection and analytical methods}

A subset of 5 fresh samples was selected for crystal preferred orientation measurements from a total of 31 samples where GSRZ were clearly identified at hand and thin section scales. Since etching by dilute chlorohydric acid of rock slabs cut parallel to the dominant GSRZ plane did not reveal any shape-preferred orientation marking a lineation in the GSRZ, high-quality polished thin sections were prepared normal to the dominant GSRZ orientation ( $Z$ direction) and parallel to the geographic North ( $X$ direction). We also analyzed the crystal preferred orientations of a spinifex-like chlorite-harzburgite with a strong olivine shape-preferred orientation (fish-tail texture, sample Al06-42), which was cut in a plane containing the average maximum and minimum elongation axes of the olivine crystals. This sample selection ensures that the whole range of GSR degrees (2-100\%, area fraction at the thin section scale) was covered (see Table 1 for details). The degree of GSR and the Ol:Opx ratio within 
and outside the GSRZ are presented in Table 1. Estimations were based on the analysis (Fovea Pro 4.0 toolbox for Adobe Photoshop ${ }^{\circledR}$ software) of high-quality cross-polarized images of thin sections from all the samples.

Crystal-preferred orientations ( $\mathrm{CPO}$ ) of olivine and orthopyroxene were measured by indexing of Electron Back Scattered Diffraction (EBSD) patterns using the SEM-EBSD systems at Geosciences Montpellier (CNRS-Université de Montpellier 2, France). Indexing was performed by automatic EBSD mapping of whole thin sections on a JEOL JSM 5600 using a regular grid step of $30-35 \mu \mathrm{m}$. The selected regular grid step of 30-35 $\mu \mathrm{m}$ is in average 2-3 times smaller than the smallest observed grains over the entire thin section. EBSD patterns were indexed automatically using CHANNEL 5 software package from HKL Technology. Raw maps are characterized by $40-50 \%$ indexed surface. Non-indexed pixels are due to serpentinization, polishing defects, and grain boundaries. Orthopyroxene was particularly illindexed in most samples because of the fine-grain size of the individual acicular crystals that compose the aggregates and their poor polishing (they form low relief domains compared to olivine during sample preparation). In order to increase the indexing rate, a post-acquisition data treatment using the CHANNEL5 software, described in detail by Tommasi et al. (2008), was performed.

Pole figures are represented using average Euler angles for each grain, instead of individual measurements, to avoid over-representation of the larger grains on the thin section. In addition, we set up a minimum grain area of $4500-6125 \mu^{2}$ (5 contiguous measurement points for measurement steps of 30 and $35 \mu \mathrm{m}$, respectively) to avoid over-representing poorly indexed grains. This minimum area is small enough not to loss information on the orientation of the smaller grains, which are on average $100 \mu \mathrm{m}$-wide. The number of indexed grains is highly variable between thin sections due to different recrystallization degrees, but usually ranges from 2000 to 14,000 grains in the GSRZ. When GSR and spinifex-like texture zones occur in the same mapped thin section a subset was created in CHANNEL 5 by manually selecting large spinifex olivine grains $\left(>700,000 \mu \mathrm{m}^{2}\right)$. This selection was verified by comparing the olivine orientation map with the scanned thin section image where the brown spinifex olivine is easily identified. The remaining data correspond to the orientation of olivine in the GSRZ. All EBSD data were processed and contoured as conventional pole figures using the software PFCH5 (Mainprice, 1990).

\subsection{Spinifex-like texture}

A striking characteristic of the chlorite-harzburgite with a spinifexlike texture is the strong correlation between olivine and orthopyroxene crystal preferred orientations: olivine [100] axes are roughly parallel to the orthopyroxene [100] ones and the same is true for the other crystallographic axes (Fig. 7). This orientation relation is rather unusual and does not correspond to the one normally observed in naturally deformed peridotites, where olivine [100] axes tend to align with the orthopyroxene [001] ones (e.g., Tommasi et al., 2004, 2006; Soustelle et al., 2010). Moreover, orthopyroxene CPO in spinifex-like chlorite-harzburgite clearly differs from those in naturally deformed peridotites as it often shows a stronger orientation of [010] relative to [001] and [100] (Fig. 7).

There is also a strong correlation between the crystal-preferred orientations (CPO) of olivine and orthopyroxene and their shape preferred orientations (SPO). The maximum elongation of both large spinifex-like olivine and acicular orthopyroxene crystals forming aggregates is parallel to their [001] axes. The minimum elongation of spinifex olivine is parallel to the [100] axis (Figs. 7a and 8a). Sample Al06-42, characterized by a strong SPO of olivine (Figs. 3a and 8a) and no GSR, shows a very strong olivine $\mathrm{CPO}$ with a bimodal distribution of [001] and [100], where the two maxima form an angle of $\sim 30^{\circ}$ around the average maximum and minimum elongation of the spinifex crystals, respectively. This bimodal distribution is well correlated to the fish-tail distribution of the spinifex crystals. Within a single olivine crystal, crystallographic orientations are remarkably homogeneous and subgrains are absent (Fig. 7a). However, the curvature of some olivine crystals (sheath shapes), probably formed during metamorphic growth, results in a gradual orientation change; in some cases, total misorientation within a single crystal may attain $15-20^{\circ}$ (Fig. 7a).

Samples that show weaker olivine SPO have more dispersed CPO. The spinifex-like olivine orientation varies, therefore, from rather strong (Fig. 7a, c, and d) to more scattered (Fig. 7e), depending on the SPO strength, but it is never random. At the thin section scale, two or more orientation families intersecting at $30-40^{\circ}$ are usually observed (Figs. 7 and 8).

\subsection{Grain size reduction zones (GSRZ)}

Despite clear correlation between the olivine CPO in the GSRZ and the orientation of the neighboring spinifex crystals, CPO in the GSRZ is more dispersed (Fig. 7b and e). This dispersion affects all three main crystallographic axes, but it is stronger for [100] and [001]. This results in a [010]-fiber olivine CPO, where [010] forms a weak point maximum $\left(\mathrm{pf}_{[010]}=1.43-2.13\right)$ roughly normal to the dominant orientation of the GSRZ (Fig. 7). The two other axes are dispersed in a wide girdle subparallel to this plane. Sample Al06-35 departs from this trend by showing a stronger concentration of [100] and a higher obliquity between the CPO and the average orientation of the GSRZ, but the correlation between the olivine CPO in the spinifex-like and adjacent GSR domains is always observed (Fig. 7e). On the other hand, there is no relation between the CPO intensity and the fraction of the sample affected by GSR. The completely recrystallized sample Al07-07 (Fig. 7f) displays the same olivine CPO pattern as the mm-wide GSRZ band in sample Al06-05a (Fig. 7b).

Inspection of crystal orientation maps (Fig. 8) reveals that all GSRZ, independently of their thickness, are composed of discrete domains with similar orientations. The size and shape of these domains (up to $1 \mathrm{~cm}$ in length) is comparable to those of the neighboring spinifex-like olivine crystals. This preservation of the original spinifex-like shape is even clearer in isolated incipient GSR pockets (Figs. 3f, 5d, and 8d). These observations corroborate the conclusions drawn from the structural observations, both at the outcrop and thin-section scales, notably: (i) GSRZ formed at the expenses of the previous metamorphic crystallization textures; and (ii) the process (or processes) responsible for the grain size reduction does not involve significant displacement across the GSRZ.

To further characterize the changes in olivine $\mathrm{CPO}$ associated with the GSR process, we analyze the distributions of misorientation angles, that is, the variations in the crystallographic orientation between two crystals. The correlated misorientation distribution, which is the one between neighboring measurement points in the

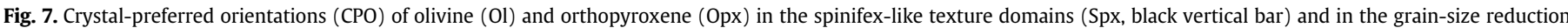

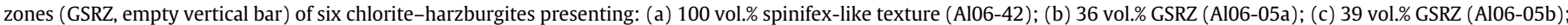

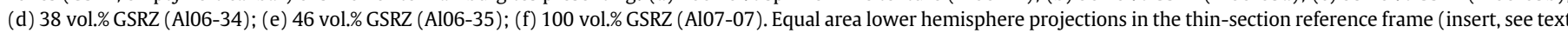

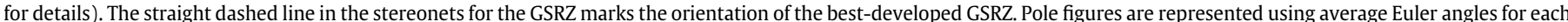

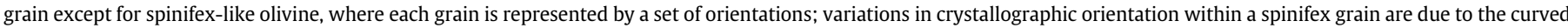

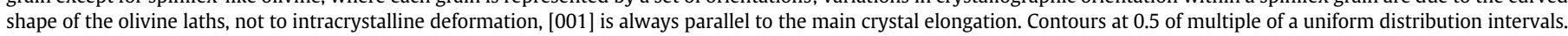
$n=$ number of grains measured; $\mathrm{pf}$ = fabric strength for each crystallographic axis. 
crystallographic orientation map, departs notably from the one expected for a random aggregate of orthorhombic crystals (solid line in Fig. 9a). In all samples the correlated distribution is highly asymmetric, with a maximum at $5-10^{\circ}$. A secondary maximum, located around $20^{\circ}$, is observed for samples Al06-05a, Al06-05b and Al07-07 (Fig. 9a). In contrast, the uncorrelated misorientation

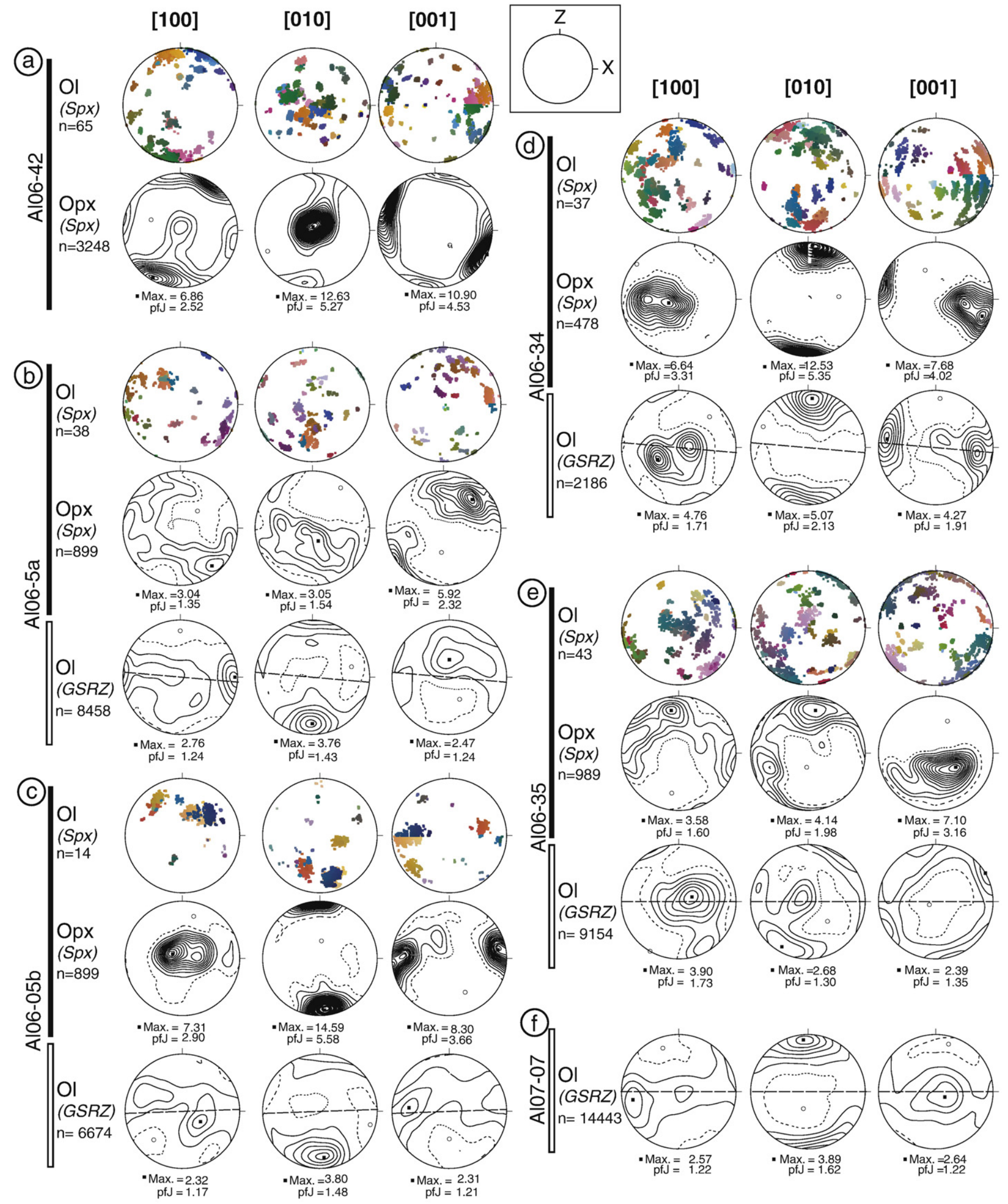


distribution of olivine, that is the misorientation between randomly chosen measurement points, in most samples matches closely the random distribution, except for samples Al06-34 and Al06-35 that show a higher proportion of misorientations $<40^{\circ}$. These uncorrelated misorientation distributions are consistent with the measured olivine $\mathrm{CPO}$, which are slightly stronger in the GSRZ of these two samples (Fig. 7). This difference between correlated and uncorrelated misorientation distributions points to a short range control on the crystal preferred orientations ( $\mathrm{mm}$-scale domains, corresponding to the original spinifex-like olivine crystals).

Analysis of the lattice rotations across all low-angle $\left(2-12^{\circ}\right)$ olivine-olivine boundaries in the GSRZ, represented as inverse pole figures in the crystal reference frame (Fig. 9b), shows that the rotations producing these misorientations are not crystallographically controlled; the inverse pole figures show almost homogeneous distributions (the minima are $>0.65$ and the maxima are $<1.69$ multiples uniform distribution). This observation is at odds with rotation axes distributions for low-angle misorientations usually measured in naturally-deformed peridotites, where a predominance of $[0 \mathrm{vw}]$ rotation axes, mainly [001] and [010], results from deformation by dislocation creep with dominant activation of [100]\{0kl\} slip systems (e.g. Tommasi et al., 2008; Soustelle et al., 2010).

\section{Discussion}

\subsection{Origin of grain size reduction zones (GSRZ) by hydrofracturing}

\subsubsection{Structural evidence}

GSRZ are characterized by: (i) dominantly planar shapes with two conjugated orientations intersecting at $40-60^{\circ}$, (ii) irregular, but sharp contacts with the host spinifex-like chlorite-harzburgite, and (iii) absence of displacement (neither shearing nor stretching) across them (Fig. 3). These features are the same irrespectively of the rock volume affected by the grain size reduction process; they are similar in large, meter-wide and in small, mm-wide GSRZ. Furthermore, the final grain size is remarkably homogeneous (Table 1) and does not depend neither on the initial spinifex olivine grains size nor on their orientation.

All these attributes are consistent with the formation of the GSRZ by brittle deformation (cataclasis) rather than by dynamic recrystallization during deformation by dislocation creep. The absence of displacement across the GSRZ, independently of thickness, and their irregular shapes and abrupt terminations point, in fact, to cataclasis induced by hydrofracturing as the main process explaining GSRZ instead of tectonic faulting. Cataclasis by hydrofracturing may also explain the irregular shapes and abrupt terminations of the GSRZ. Although the orientation of the GSRZ shows a strong dispersion and varies between different sections of the massif (Fig. 4a), analysis of the orientation of wide GSRZ at the scale of the massif highlights two main conjugated planes (Fig. 4c). This points to a contribution of a large-scale, regional stress field to the geometric distribution of the brittle deformation.

Self-similar patterns and non-random distributions of geometric frameworks are distinctive features of brittle deformation by hydrofracturing in metamorphic terrains (e.g., Manning, 1994a,b; Toriumi and Hara, 1995). Complex fracture networks occur, for instance, in the high pressure ultramafic terrain of Almklovdalen (western Norway), where they were interpreted as hydrofractures produced during 'forcefully' introduced external fluids (Kostenko et al., 2002). Fracturing can also be produced during mineral replacement processes (e.g., Jamtveit et al., 2008, 2009). Planar fractures would represent high permeability zones, forming preferential pathways for the escape for overpressured fluids produced by dehydration reactions within the metamorphic sequence. Feedback between brittle deformation and fluid flow may lead to a sharp front delimiting domains where grain boundaries were pervasively infiltrated by fluids produced by prograde metamorphic reactions as described in the Almklovdalen massif (Kostenko et al., 2002), in the Bergen Alps (Jamtveit et al., 1990, 2000) and in contact metamorphic terrains (Holness and Watt, 2001, 2002). Sharp contacts between GSRZ and the host spinifex-like or granofels chlorite-harzburgite are also systematically observed in the Cerro del Almirez ultramafic massif, thus corroborating an hydrofracturing origin for the GRSZ.

\subsubsection{Evidence from the microstructure and $\mathrm{CPO}$ of olivine}

Analysis of the olivine microstructures further supports a brittle rather than a ductile mechanism (i.e., grain size reduction by dynamic recrystallization during dislocation creep) for the formation of GSRZ. The observations corroborating this interpretation at the microscopic scale are: (i) the presence of isolated GSR pockets (Figs. 3e, f, and 5d), (ii) the abrupt termination of irregular GSRZ and their lack of lateral continuity (Fig. 3c), (iii) the lack of displacement across the GSRZ, and (iv) the preservation of the original spinifex-like shape in partially (Fig. 5d) or completely recrystallized crystals (Fig. 8b, c, and d). All these features imply that the process responsible for the grain size reduction in the Cerro del Almirez chlorite-harzburgite is not associated with ductile strain (i.e., a change of shape) of the olivine crystals. This rules out recrystallization due to ductile deformation, since the latter occurs in response to the accumulation of dislocations in the crystals and is a strain-dependent process.

The presence of a well-developed CPO is usually a diagnostic feature of deformation by dislocation creep. However, the high correlation between olivine and orthopyroxene CPOs in the spinifexlike texture domains and in neighboring GSRZ (Fig. 7b, c, d, and e) suggests that the crystallographic orientation in GSRZ is mainly inherited from the preexisting CPO in the host peridotite. Indeed, well-defined olivine CPO in GSRZ is observed in samples with a strong coherent orientation of both olivine and orthopyroxene in the relictspinifex-like textured zone (Fig. 7b, c and d), whereas the sample with the least oriented spinifex-like texture shows a weak olivine $\mathrm{CPO}$ in the adjacent GSRZ (Fig. 7e). The systematically weaker CPO in the GSRZ relatively to the adjacent spinifex-like texture domains indicates, nevertheless, that the grain size reduction process results in a dispersion of the original orientation.

Analysis of the misorientation angle distribution enables further discrimination between ductile or brittle deformation mechanisms. Dynamic recrystallization by subgrain rotation results in a predominance of low-angle misorientations and in characteristic rotation axes in the crystal reference frame, since both the orientation of the subgrain boundary and the misorientation across it are directly related to the dislocations forming the boundary (Amelinckx and Dekeyser, 1959). The analysis of the rotation axes accommodating low-angle misorientations may thus be used to infer active slip systems. For instance, deformation by dislocation creep with dominant activation of high-temperature, low-stress $(0 \mathrm{kl})[100]$ slip systems would result in rotation axes parallel to [001] and [010] (Tommasi et al., 2000; Soustelle et al., 2010); this pattern can be observed even in strongly annealed peridotites (Tommasi et al., 2008; Vauchez and Garrido, 2001). Brittle deformation, on the other hand, leads to random rotation axes.

Orientation maps (Fig. 8b, c, and d) show that GSRZ consist of relatively large discrete domains (up to $1 \mathrm{~cm}$ long) with roughly similar orientations. This supports a strong inheritance from preexisting large grains. Furthermore, the correlated misorientation distribution for olivine (that is, between neighboring measurement points in the map) is characterized by maxima at relatively highmisorientation angles (at $\sim 5-10^{\circ}$ and $\sim 20^{\circ}$, Fig. 9a) that significantly differ from those observed in olivine-rich rocks deformed by dislocation creep $\left(<5^{\circ}\right)$. Moreover, the rotation axes accommodating low-angle misorientations in the GSRZ display a very weak crystallographic control (Fig. 9b), which is not consistent with deformation by dislocation creep. 


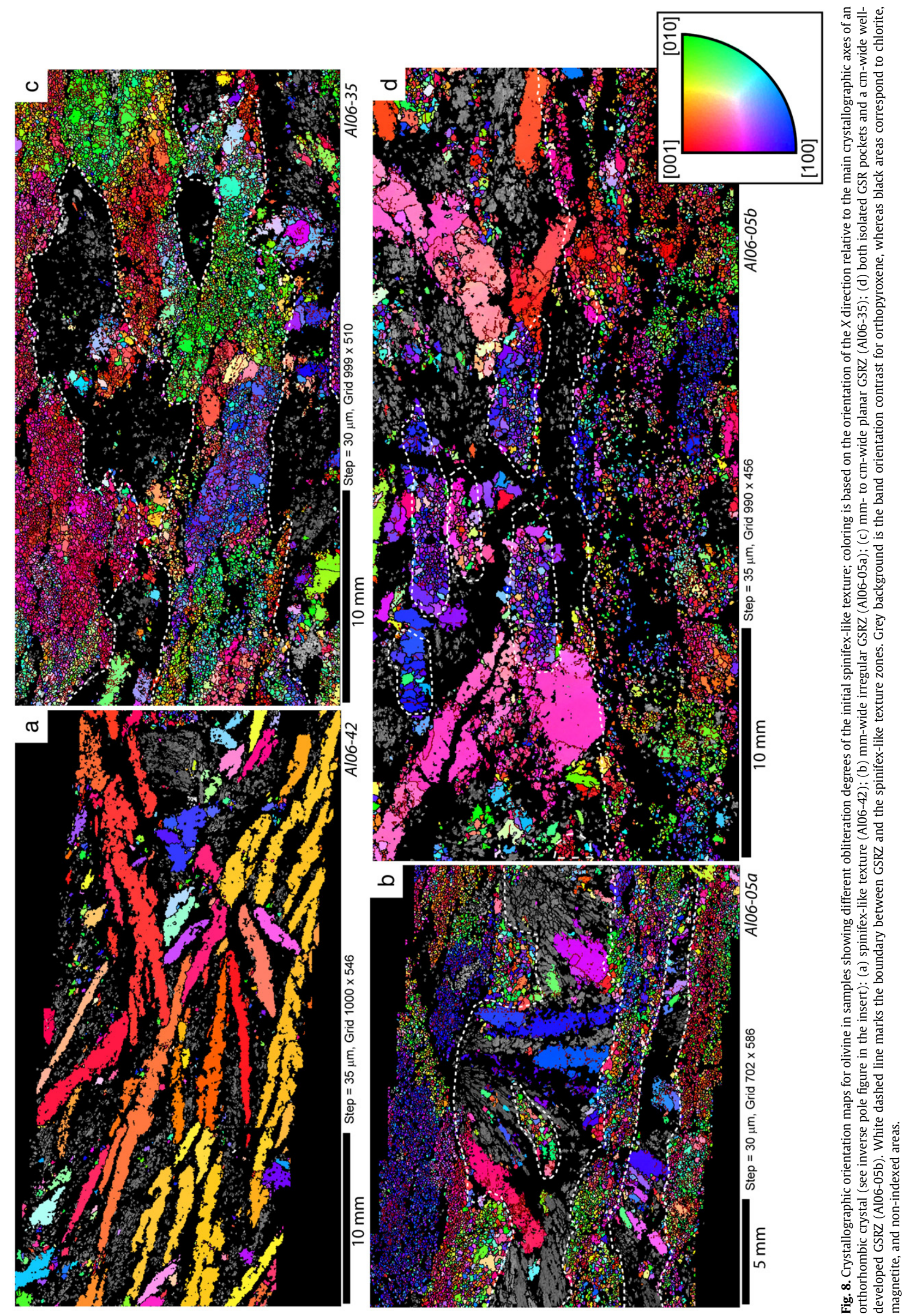



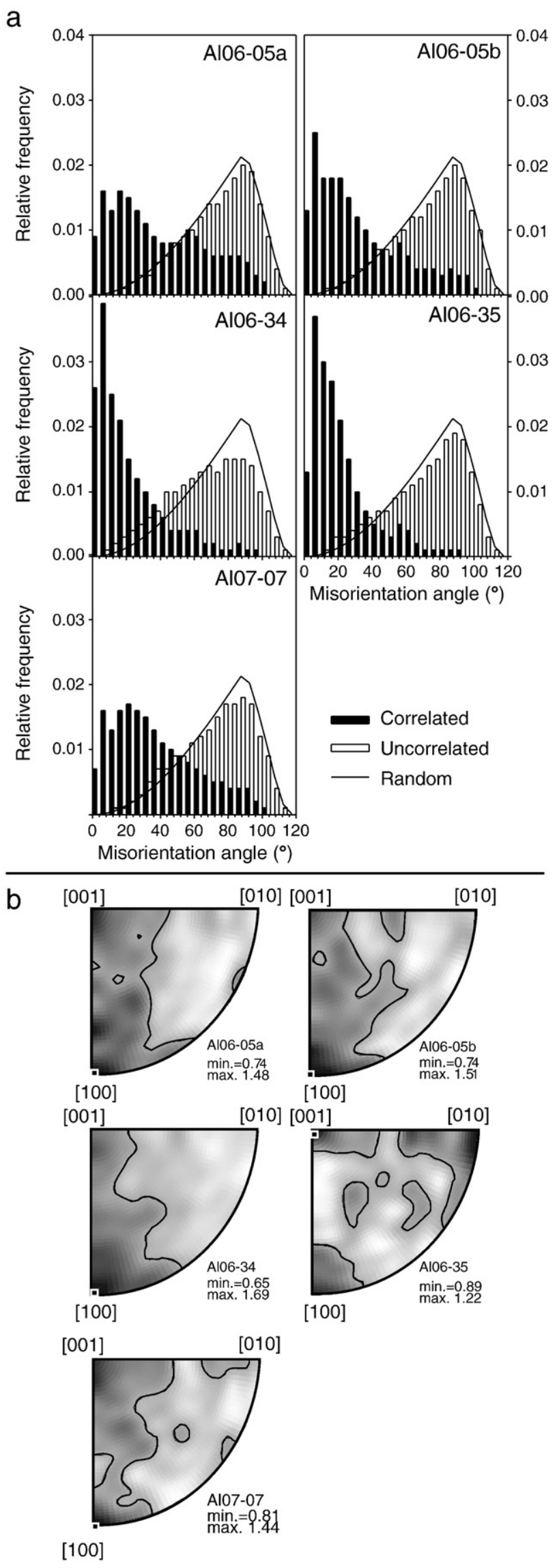

The extremely low dislocation densities (Fig. 6a) and the rare occurrence of dislocations with glide morphologies (Fig. 6c) also imply that dislocation creep was not a major process leading to grain size reduction. The observed radial dislocations in polygonal olivine crystals from GSRZ (Fig. 6a, b) are rather indicative of fast growth, probably assisted by fluids. Olivine with well-developed crystallographic faces (tablets) and straight dislocations normal to the faces is common in peridotite nodules in kimberlites, where growth rates are constrained by their fast ascent rates (Guéguen, 1977; Arndt et al., 2010). Based on the similarity of the morphology and dislocation structure of the olivine tablets with those formed in synthetic hydrothermally grown quartz crystals (Michot et al., 1984), Arndt et al. (2010) proposed that fast growth of these faceted olivine crystals has been assisted by a fluid film at their grain boundaries, in agreement with previous suggestions by Guéguen (1977) and Drury and Roermund (1989).

Although PT conditions during the formation of the GSRZ cannot be accurately constrained by thermobarometry, the similarity of mineral assemblages in the GSRZ and spinifex-like chlorite-harzburgites suggests that deformation took place close to the metamorphic peak of the latter. Occurrence of tremolite constrains a maximum temperature of $680-710{ }^{\circ} \mathrm{C}$ for the pressure range of $1.6-1.9 \mathrm{GPa}$ (López Sánchez-Vizcaíno et al., 2005; Padrón-Navarta et al., 2010). Under dry conditions, these low-temperature conditions would imply very slow diffusion rates and should prevent grain growth. A fluidrich environment might, however, allow grain growth even under lower temperature conditions.

The association of hydrofracturing and grain growth in presence of fluids may also account for the release of the solid and fluid inclusions from the preexisting brownish spinifex-like olivine and for the related color change. Static grain growth simulations (Jessell et al., 2003) show that microstructural defects are easily swept by grain boundary migration. Hydrofracturing followed by static grain growth has indeed been proposed to account for local grain coarsening and decrease in the inclusions density at the olivine rims in the Almklovdalen peridotite in west Norway (Kostenko et al., 2002; Jessell et al., 2003). Grain sizes of recrystallized olivine in the Cerro del Almirez are smaller than those in the Almklovdalen peridotite, in accordance with the lower temperature conditions of formation of the GSRZ in Cerro del Almirez.

\subsubsection{Fluid focusing in hydrofractures and orthopyroxene dissolution}

A striking feature of the GSRZ is the substantial reduction of the orthopyroxene modal content compared to spinifex-like textured domains (Table 1, Fig. 8). This suggests that crystallization of olivine at the expense of orthopyroxene might have occurred during the grain size reduction process. This reaction would imply open system conditions, characterized by the presence of a reactive, interconnected, silica-undersaturated fluid phase during the formation of the GSRZ, consistently with microstructural observations that point to hydrofracturing.

The composition and source of the reactive fluids cannot be assessed unambiguously, but a possible source is the antigorite-out dehydration reaction, since the GSRZ are formed within tens to hundred meters from the reaction front (Fig. 4). It has been shown experimentally that the fluids produced by this reaction are water-rich and contain $\sim 6 \mathrm{wt} . \% \mathrm{SiO}_{2}, \sim 2 \mathrm{wt} . \% \mathrm{MgO}, \sim 1 \mathrm{wt} . \% \mathrm{CaO}$, and $\sim 1 \mathrm{wt} . \%$ $\mathrm{Al}_{2} \mathrm{O}_{3}$ (Tenthorey and Hermann, 2004). Calculated curves for silica

Fig. 9. (a) Misorientation frequency distribution in the GSRZ for all samples except Al06-42. Correlated are misorientations between neighboring points, uncorrelated are misorientations between non-neighboring points selected randomly, and random indicates the theoretical distribution for an olivine random crystallographic orientation; (b) Inverse pole figure (IPF) of the rotation axes accommodating misorientations within grains and across subgrain boundaries in the crystal reference frame for the same samples. Because of the almost random distribution data has been only contoured at 1 multiple of uniform distribution (m.u.d.). 
solubility (Manning, 1994a,b) indicate a maximum $\mathrm{SiO}_{2}$ solubility of $4-6$ wt.\% at $650-700{ }^{\circ} \mathrm{C}$ and $1.5-2.0 \mathrm{GPa}$. The ability of the fluids produced by the antigorite dehydration to dissolve orthopyroxene under the conditions inferred for the formation of the GSRZ is therefore rather low. One possible explanation allowing to reconcile the observed reduction in the orthopyroxene content in the GSRZ and the experimental data would be an increase of the silica solubility in the fluid during the hydrofracturing process because of the more reactive character of overpressured fluids (Manning, 1994a,b).

Although a balanced reaction between the host chlorite-harzburgite and these silica undersaturated fluids cannot be precisely constrained due to the unknown fluid composition, a relative volume change was probably involved in this reaction. In fact, a simple estimation can be made by considering, on the one hand, the difference in modal composition between the host spinifex-like domains and GSRZ (Table 1) and, on the other hand, the molar volumes, computed at 1.6-1.9 GPa and $680{ }^{\circ} \mathrm{C}$, for olivine $\left(43.60-43.53 \mathrm{~cm}^{3} / \mathrm{mol}\right)$ and orthopyroxene $\left(62.25-62.13 \mathrm{~cm}^{3} / \mathrm{mol}\right.$ ) (Holland and Powell, 1998). We estimate a rock volume decrease of $13-15$ vol.\% associated to the formation of GSRZ. During reaction processes, total solid volume reductions by about 10 vol.\% (Austrheim, 1987, Jamtveit et al., 1990, 2000) can accelerate the fluid transport by perturbation of the local field stress. This mechanism may enhance fluid transport over longer distances than those expected based only on grain-boundary diffusion (Jamtveit et al., 2000, 2009).

\subsection{GSRZ as pathways for fluids from antigorite dehydration front}

Embrittlement and weakening owing to dehydration reactions has been recognized since the earliest experimental works on serpentinite deformation (Raleigh and Paterson, 1965). The two processes were attributed to a transient reduction of the effective confining pressure due to an increase of the fluid pressure. This effect has been commonly invoked to explain both intermediate- and deep-focus earthquakes in subduction zones (Nishiyama, 1989; Peacock, 2001; Dobson et al., 2002; Tenthorey and Cox, 2003; Hacker et al., 2003; Seno and Yamasaki, 2003; Jung et al., 2004). Ubiquitous occurrence of olivine veins with prograde assemblages in serpentinites from high grade terrains point also to brittle deformation during dehydration (Strating and Vissers, 1991; Scambelluri et al., 1991; Healy et al., 2009; López Sánchez-Vizcaíno et al., 2009). These field observations are, nevertheless, solely relevant for partial dehydration reactions (brucite breakdown), and not for the complete antigorite dehydration (Trommsdorff et al., 1998). In contrast, other dehydration reactions, like the transformation of diaspore into corundum, produce macroscopic ductile structures rather than brittle ones (Urai and Feenstra, 2001; Feenstra and Wunder, 2002).

These apparently contradictory observations can be explained by a time-dependent feedback between the evolution of the fluid pressure and deformation during dehydration. Coupled metamorphicrheological numerical simulations (Connolly, 1997; Connolly and Podladchikov, 1998, Connolly, 2010) have shown that positive fluid pressure anomalies produced at the dehydration reaction front can be propagated by creep mechanisms over large distances, hindering hydrofracturing if viscous relaxation times are short enough. Alternatively, microcraking by inter- and intragrain hydrofracturing will occur when viscous relaxation times are long and the fluid pressure exceeds the minimum principal stress and the tensile strength of the rock (Connolly, 2010).

There is an increasing body of evidence for the role of microcracks as an effective mechanism to enhance fluid flow during dehydration (Miller et al., 2003; Ko et al., 1997). Experiments confirm that reactioninduced microcraking is an efficient mechanism at enhancing anatectic melt extraction, for instance, although extraordinarily fast reaction rates are required (Connolly et al., 1997; Watt et al., 2000). Therefore, transient fluid flow will depend on the interplay between the rheology and permeability of the rock matrix and the fluid production rate. Perrillat et al. (2005) estimated that water production rates for the antigorite dehydration $\left(3 \times 10^{-6}\right.$ to $3 \times 10^{-8} \mathrm{~m}_{\text {fluid }} \mathrm{m}^{-3}$ rock $\left.\mathrm{s}^{-1}\right)$ largely exceed the strain rates inferred for viscous relaxation in serpentinites, allowing for reaction-induced embrittlement. As pointed out by these authors, these values are nevertheless strongly dependent on the grain size. Their fluid production rates should thus be taken as an upper bound for the experimental powder grain size $(1-10 \mu \mathrm{m})$ is significantly lower than those observed in natural high-grade serpentinites (10-50 $\mu \mathrm{m}$, e.g., Fig. 2 in Padrón-Navarta et al., 2008).

In order to estimate the porosity production and the overpressure (related with the positive volume change of the reaction, $\Delta V_{\text {rxn }}$ ) linked to the antigorite dehydration, we computed the solid and reaction volume changes for the following balanced reaction:

$$
\begin{aligned}
& \mathrm{Mg}_{46.5} \mathrm{Al}_{3} \mathrm{Si}_{32.5} \mathrm{O}_{85}(\mathrm{OH})_{62}=11 \underset{\text { antigorite }\left(3.4 \text { wr } \% \mathrm{Al}_{2} \mathrm{SiO}_{4} \mathrm{O}_{3}\right)}{\mathrm{Mr}_{3}}+8.5 \underset{\text { enstatite }}{\mathrm{Mg}_{2} \mathrm{Si}_{2} \mathrm{O}_{6}} \\
& +\underset{\text { clinochlore }}{1.5 \mathrm{Mg}_{5} \mathrm{Al}_{2} \mathrm{Si}_{3} \mathrm{O}_{10}(\mathrm{OH})_{8}}+25 \mathrm{H}_{2} \mathrm{O} \text {. }
\end{aligned}
$$

We used Perple_X (Connolly, 2005), with the updated version of the mineral database from Holland and Powell (1998), the CORK fluid equation of the state (Holland and Powell, 1991, 1998), a representative antigorite composition in terms of $\mathrm{Al}_{2} \mathrm{O}_{3}$ content (e.g. PadrónNavarta et al., 2008) and new compressibility data for antigorite, fitted by a third-order Birch-Murnaghan equation of state (Nestola et al., 2010), at the pressure and temperature conditions relevant for the antigorite dehydration at Cerro del Almirez (1.7-1.9 GPa and $680^{\circ} \mathrm{C}$ ).

Results show a significant porosity production due to solid volume decrease $\left(\Delta V_{\text {solids }} \sim-21.5\right.$ vol.\%) and a moderate positive increase of the total volume of the reaction $\left(\Delta V_{\mathrm{rxn}}=+2.3-2.7\right.$ vol.\%). In the Cerro del Almirez ultramafics, micro- and macrostructures that can be attributed to hydrofracturing related to the antigorite dehydration are only observed in the prograde chlorite-harzburgite. This is a logical consequence of the highly contrasting rheological behavior of serpentinites and peridotites. Recent deformation experiments (Hilairet et al., 2007) suggest that viscous relaxation times for antigorite at high pressure conditions are at least 10 orders of magnitude shorter than those for olivine. Accordingly, we propose that fluid released during the antigorite dehydration may have been drained through porosity propagation by viscous creep in the serpentinites, but by hydrofracturing in the higher viscosity chlorite-harzburgite. In this scenario, GSRZ would be the relic evidences of such fluid propagation through microcraking mechanisms. On the other hand, the systematic orientation of the larger GSRZ at the outcrop scale (Fig. 4) suggests that a large-scale stress field might have also affected these rocks. Changes in the regional stress field, due to large intermediate depth earthquakes, for instance (Abers et al., 2009), may enhance reaction rates and favor the development of local overpressure.

\subsection{Hydrofracturing in the cold mantle wedge and slab: implications for subduction zones}

Field evidences suggest that hydrofracturing is a common process at high- (Toriumi and Hara, 1995; Pennacchioni, 1996; Cesare et al., 2001) and ultra-high-pressure conditions (Vrijmoed et al., 2006, 2008; Malaspina et al., 2009). Hydrofracturing has also been proposed to account for deep-crustal seismicity (Lund and Austrheim, 2003; Andersen et al., 2008). A large body of evidence also attests for the importance of brittle deformation in subduction zones: field observations of brittle failure in exhumed subducted rocks (Hermann et al., 2000; John et al., 2004; Healy et al., 2009); evidences for hydraulic fracturing during hydrous metasomatism of mantle wedge xenoliths (Wilshire and Kirby, 1989; Schneider and Eggler, 1986; McInnes et al., 2001; Soustelle et al., 2010); dehydration experiments (Miller et al., 
2003; Tenthorey and Cox, 2003; Perrillat et al., 2005); seismicity, including episodic tremor and slip and regular intermediate-depth earthquakes (Kirby et al., 1996; Obara, 2002; Rogers and Dragert, 2003; Shelly et al., 2006; Abers et al., 2009); and numerical models (Furukawa, 2009).

Based on the field and microstructural observations presented above, we propose that hydrofracturing is a plausible mechanism for the transport of fluids produced by dehydration reactions across an otherwise almost impermeable cold, top-slab mantle wedge. Our observations are consistent with a scenario where the migration of the fluids produced by dehydration reactions in the slab and in the serpentine-rich channel above the slab, is slowed down when they reach the cold and, hence, high-viscosity peridotites in contact with the upper part of the slab, thus promoting the required overpressure for hydrofracturing. This process, which results in the formation of the GSRZ, enhances the permeability and allows the fluids to attain the hotter parts of the mantle wedge.

This high-pressure hydrofracturing, however, would only result in a minor seismological signal (low magnitude events, more akin to seismic tremors) due to the absence of displacement associated with the formation of GSRZ. The resulting intermediate-depth (50-70 km), lowmagnitude seismic events would be very difficult to be detected. The described porosity enhancement and near-lithostatic fluid pressures should, nevertheless, produce transient low seismic velocities, high Poisson ratios, and high attenuation zones, similar to those associated with episodic tremor and slip ETS in the Nankai and Cascadia subduction zones (Kodaira et al., 2004; Abers et al., 2009; Audet et al., 2009). The latter nucleate near to the slab interface (La Rocca et al., 2009), as expected for the hydrofracturing mechanism proposed here, but are usually restricted to $<40 \mathrm{~km}$ depth (Shelly et al., 2006; Abers et al., 2009) and cannot be directly related to the high-pressure processes observed in the Cerro del Almirez chlorite-harzburgite.

\section{Conclusions}

Chlorite-harzburgite is the expected lithology in the cold, top-slab mantle wedge, a key layer controlling the transport of the fluids released from deep slab dehydration reactions. Based on detailed field and microstructural observations of this lithology in the high-pressure Cerro del Almirez ultramafic massif (Betic Cordillera, Spain) we reach the following conclusions:

(a) Anisomorphic growth of olivine and orthopyroxene in the spinifex-textured chlorite-harzburgite represents a primary metamorphic crystallization texture, characterized by a strong correlation between the crystal-preferred orientations (CPO) of olivine and orthopyroxene and their shape preferred orientation (SPO).

(b) This primary metamorphic texture was affected by mm- to mscale grain-size reduction zones (GSRZ). These GSRZ are most commonly roughly planar structures with two main conjugated orientations, intersecting at $40-60^{\circ}$. Irregularly shaped, small-scale ( $\mathrm{mm}$ to $\mathrm{cm}$ ) GSR pockets exist too. GSRZ display a series of distinctive features, similar at all scales: (1) irregular sharp contacts with the host undeformed peridotite, (2) lack of displacement across them, (3) remarkable homogeneity of the olivine grain size irrespective of the rock volume affected by recrystallization, (4) a decrease in the orthopyroxene content, and (5) extremely low dislocation densities in the recrystallized olivine. All these features, together with the irregular shapes and abrupt terminations of the small-scale of GSRZ, rule out formation of the GSRZ by dislocation creep and are consistent with brittle deformation.

(c) Brittle deformation also results in dispersion of the olivine crystals orientation in the GSRZ, but a strong inheritance from the precursor spinifex-like texture in the chlorite-harzburgite can still be recognized. Large discrete domains (up to $1 \mathrm{~cm}$ long) with low misorientations are preserved in the GSRZ; they correspond to former spinifex-like olivine crystals. These domains result in a short range control on the crystal preferred orientations, hence causing differences between the correlated and uncorrelated olivine misorientation distribution. The almost random distribution of the rotation axes accommodating low-angle misorientations in the GSRZ is a further evidence for brittle deformation.

Based on these microstructural observations we propose that hydrofracturing is the main mechanism accounting for grain size reduction in the Cerro del Almirez chlorite-harzburgite. The flux of an overpressured fluid through the GSRZ is also supported by substantial reduction of the orthopyroxene modal content compared with the spinifex textured domains. Development of the GSRZ network was thus probably linked to the fluid release during the antigorite dehydration. Microcraking may allow the formation of high permeability channel ways for overpressured fluids in an otherwise almost impermeable and cold $\left(680-710^{\circ} \mathrm{C}\right)$ peridotite. We suggest that this high-pressure hydrofracturing may be an essential mechanism in the first stages of fluid flow through the coldest parts of top-slab mantle in subduction zones, before the fluids attain the hotter parts of the mantle wedge where their migration may be assisted by viscoplastic deformation processes. The near-lithostatic pressures associated with this process will produce transient low seismic velocities, high Poisson ratios, and high attenuation zones, similar to those associated with episodic tremor and slip attenuation zones.

\section{Acknowledgements}

Two anonymous reviewers are thanked for their insightful and helpful reviews. D. Mainprice and P. Cordier are thanked for discussions on the olivine CPO and dislocation structures. D. Mainprice is also thanked for providing softwares for analyzing and plotting CPO data. C. Nevado supplied high quality polished thin sections for EBSD measurements. We thank F. Barou for his technical assistance in the EBSD facilities at Geosciences Montpellier. M.J. Rodríguez-Peces is thanked for the image analysis of Fig. 3 and V. Soustelle for his help with the decoration of dislocations in olivine. This work was supported by the Spanish "Ministerio de Ciencia e Innovación (MICINN)" through research grants CGL2006-04440, CGL2007-61205/BTE, Topolberia Consolider-Ingenio CSD200600041, and by the "Junta de Andalucía" research groups RNM-145 and RNM-131, and research grant 2009-RNM-4495. J.A. PadrónNavarta is supported by fellowship AP2005-060 from the "Programa de Formación del Profesorado Universitario".

\section{References}

Abers, G.A., MacKenzie, L.S., Rondenay, S., Zhang, Z., Wech, A.G., Creager, K.C., 2009 Imaging the source region of Cascadia tremor and intermediate-depth earthquakes. Geology 37, 1119-1122.

Ague, J.J., 2003. Fluid flow in the deep crust. Treatise on Geochemistry. Pergamon, Oxford, pp. 195-228.

Amelinckx, S., Dekeyser, W., 1959. The structure and properties of grain boundaries Solid State Phys.-Adv. Res. Appl. 8, 325-499.

Andersen, T.B., Mair, K., Austrheim, H., Podladchikov, Y., Vrijmoed, J.C., 2008. Stress release in exhumed intermediate and deep earthquakes determined from ultramafic pseudotachylyte. Geology 36, 995-998.

Arcay, D., Doin, M.P., Tric, E., Bousquet, R., de Capitani, C., 2006. Overriding plate thinning in subduction zones: Localized convection induced by slab dehydration. Geochem. Geophys. Geosyst. 7.

Arcay, D., Tric, E., Doin, M.P., 2005. Numerical simulations of subduction zones: effect of slab dehydration on the mantle wedge dynamics. Phys. Earth Planet. Inter. 149, 133-153.

Arndt, N.T., Guitreau, M., Boullier, A.M., Le Roex, A., Tommasi, A., Cordier, P., Sobolev, A., 2010. Olivine, and the origin of kimberlite. J. Petrol. 51, 573-602.

Audet, P., Bostock, M.G., Christensen, N.I., Peacock, S.M., 2009. Seismic evidence for overpressured subducted oceanic crust and megathrust fault sealing. Nature 457 76-78. 
Austrheim, H., 1987. Eclogitization of lower crustal granulites by fluid migration through shear zones. Earth Planet. Sci. Lett. 81, 221-232.

Brown, K.M., Tryon, M.D., DeShon, H.R., Dorman, L.M., Schwartz, S.Y., 2005. Correlated transient fluid pulsing and seismic tremor in the Costa Rica subduction zone. Earth Planet. Sci. Lett. 238, 189-203.

Cesare, B., Poletti, E., Boiron, M.-C., Cathelineau, M., 2001. Alpine metamorphism and veining in the Zentralgneis Complex of the SW Tauern Window: a model of fluidrock interactions based on fluid inclusions. Tectonophysics 336, 121-136.

Connolly, J.A.D., 1997. Devolatilization-generated fluid pressure and deformationpropagated fluid flow during prograde regional metamorphism. J. Geophys. Res $112,18149-18173$

Connolly, J.A.D., 2005. Computation of phase equilibria by linear programming: a tool for geodynamic modeling and its application to subduction zone decarbonation. Earth Planet. Sci. Lett. 236, 524-541.

Connolly, J.A.D., 2010. The mechanics of metamorphic fluid expulsion. Elements 6, 165-172

Connolly, J.A.D., Holness, M.B., Rubie, D.C., Rushmer, T., 1997. Reaction-induced microcraking: an experimental investigation of a mechanism for enhancing anatectic metal extraction. Geology 25, 591-594.

Connolly, J.A.D., Podladchikov, Y., 1998. Compactation-driven fluid flow in viscoelastic rock. Geodin. Acta 11, 55-84.

Dobson, D.P., Meredith, P.G., Boon, S.A., 2002. Simulation of subduction zone seismicity by dehydration of serpentine. Science 298, 1407-1410.

Drury, M.R., Roermund, H.L.M.V., 1989. Fluid assisted recrystallization in upper mantle peridotite xenoliths from kimberlites. J. Petrol. 30, 133-152.

Feenstra, A., Wunder, B., 2002. Dehydration of diasporite to corundite in nature and experiment. Geology 30, 119-122.

Furukawa, Y., 2009. Convergence of aqueous fluid at the corner of the mantle wedge: implications for a generation mechanism of deep low-frequency earthquakes. Tectonophysics 469, 85-92.

Garrido, C.J., López Sánchez-Vizcaíno, V., Gómez-Pugnaire, M.T., Trommsdorff, V., Alard, O., Bodinier, J.L., Godard, M., 2005. Enrichment of HFSE in chlorite-harzburgite produced by high-pressure dehydration of antigorite-serpentinite: Implications for subduction magmatism. Geochem. Geophys. Geosyst. 6 .

Gerya, T., Connolly, J.A.D., Yuen, D.A., 2008. Why is terrestrial subduction one-sided? Geology 36, 43-46.

Gerya, T.V., Yuen, D.A., 2003. Rayleigh-Taylor instabilities from hydration and melting propel 'cold plumes' at subduction zones. Earth Planet. Sci. Lett. 212, 47-62.

Guéguen, Y., 1977. Dislocations in mantle peridotite nodules. Tectonophysics 39, 31-254.

Guillot, S., Agar, P., Hattori, K., Schwartz, S., Vidal, O., 2009. Exhumation processes in oceanic and continental context: a review. In: Lallemand, S., Funiciello, F. (Eds.), Subduction Zone Geodynamics: Frontier in Earth Sciences, pp. 175-205.

Hacker, B.R., 2008. $\mathrm{H}_{2} \mathrm{O}$ subduction beyond arcs. Geochem. Geophys. Geosyst. 9.

Hacker, B.R., Peacock, S.M., Abers, G.A., Holloway, S.D., 2003. Subduction factory -2. Are intermediate-depth earthquakes in subducting slabs linked to metamorphic dehydration reactions? J. Geophys. Res. Solid Earth 108 art. no.-2030.

Healy, D., Reddy, S.M., Timms, N.E., Gray, E.M., Brovarone, A.V., 2009. Trench-paralle fast axes of seismic anisotropy due to fluid-filled cracks in subducting slabs. Earth Planet. Sci. Lett. 283, 75-86.

Hermann, J., Müntener, O., Scambelluri, M., 2000. The importance of serpentinite mylonites for subduction and exhumation of oceanic crust. Tectonophysics 327 225-238.

Hermann, J., Spandler, C., Hack, A., Korsakov, A.V., 2006. Aqueous fluids and hydrous melts in high-pressure and ultra-high pressure rocks: implications for element transfer in subduction zones. Lithos 92, 399-417.

Hilairet, N., Reynard, B., Wang, Y.B., Daniel, I., Merkel, S., Nishiyama, N., Petitgirard, S. 2007. High-pressure creep of serpentine, interseismic deformation, and initiation of subduction. Science 318, 1910-1913.

Holland, T., Powell, R., 1991. A Compensated-Redlich-Kwong (CORK) equation for volumes and fugacities of $\mathrm{CO}_{2}$ and $\mathrm{H}_{2} \mathrm{O}$ in the range 1 bar to $50 \mathrm{kbar}$ and 100 $1600{ }^{\circ} \mathrm{C}$. Contrib. Mineral. Petrol. 109, 265-273.

Holland, T.J.B., Powell, R., 1998. An internally consistent thermodynamic data set for phases of petrological interest. J. Metamorph. Geol. 16, 309-343.

Holness, M.B., Watt, G.R., 2001. Quartz recrystallization and fluid flow during contact metamorphism: a cathodoluminescence study. Geofluids 1, 215-228.

Holness, M.B., Watt, G.R., 2002. The aureole of the Traigh Bhàn na Sgùrra Sill, Isle of Mull: reaction-driven micro-cracking during pyrometamorphism. J. Petrol. 43, 511-534.

Holtzman, B.K., Kohlstedt, D.L., Zimmerman, M.E., Heidelbach, F., Hiraga, T., Hustoft, J., 2003. Melt segregation and strain partitioning: implications for seismic anisotropy and mantle flow. Science 301, 1227-1230.

Hürlimann, R., 1999. Die Hochdruckmetamorphose der Ultramafika und der angrenzenden Nebengesteine am Cerro de Almirez, Sierra Nevada, Südspanien. Teil Il. Unpublished Diplomarbeit., ETH, 1999.

IGME, 1981. Mapa Geológico de España escala 1/50,000 (MAGNA). Hoja núm. 1028 Instituto Geológico y Minero de España.

Jamtveit, B., Bucher-Nurminen, K., Austrheim, H., 1990. Fluid controlled eclogitization of granulites in deep crustal shear zones, Bergen arcs, Western Norway. Contrib. Mineralog. Petrol. 104, 184-193.

Jamtveit, B., Austrheim, H., Malthe-Sorenssen, A., 2000. Accelerated hydration of the Earth's deep crust induced by stress perturbations. Nature 408, 75-78.

Jamtveit, B., Malthe-Sorenssen, A., Kostenko, O., 2008. Reaction enhanced permeability during retrogressive metamorphism. Earth Planet. Sci. Lett. 267, 620-627.

Jamtveit, B., Putnis, C., Malthe-Sørenssen, A., 2009. Reaction induced fracturing during replacement processes. Contrib. Mineralog. Petrol. 157, 127-133.

Jessell, M.W., Kostenko, O., Jamtveit, B., 2003. The preservation potential of microstructures during static grain growth. J. Metamorph. Geol. 21, 481-491.
John, T., Scherer, E.E., Haase, K., Schenk, V., 2004. Trace element fractionation during fluid-induced eclogitization in a subducting slab: trace element and $\mathrm{Lu}-\mathrm{Hf}-\mathrm{Sm}-\mathrm{Nd}$ isotope systematics. Earth Planet. Sci. Lett. 227, 441-456.

Jung, H., Green, H.W., Dobrzhinetskaya, L.F., 2004. Intermediate-depth earthquake faulting by dehydration embrittlement with negative volume change. Nature 428 , 545-549.

Kelemen, P.B., Dick, H.J.B., 1995. Focused melt flow and localized deformation in the upper-mantle - juxtaposition of replacive dunite and ductile shear zones in the Josephine peridotite, SW Oregon. J. Geophys. Res. Solid Earth 100 (B1), 423-438.

Kirby, S.H., Stein, S., Okal, E.A., Rubie, D.C., 1996. Metastable mantle phase transformations and deep earthquakes in subducting oceanic lithosphere. Rev. Geophys. 34, 261-306.

Ko, S.C., Olgaard, D.L., Wong, T.F., 1997. Generation and maintenance of pore pressure excess in a dehydrating system: 1. Experimental and microstructural observations. J. Geophys. Res. 102, 825-839.

Kodaira, S., Iidaka, T., Kato, A., Park, J.-O., Iwasaki, T., Kaneda, Y., 2004. High pore fluid pressure may cause silent slip in the Nankai Trough. Science 304, 1295-1298.

Kohlstedt, D.L., Goetze, C., Durham, W.B., Vandersande, J., 1976. New technique for decorating dislocations in olivine. Science 191, 1045-1046.

Kostenko, O., Jamtveit, B., Austrheim, H., Pollok, K., Putnis, C., 2002. The mechanism of fluid infiltration in peridotites at Almklovdalen, western Norway. Geofluids 2, 203-215.

La Rocca, M., Creager, K.C., Galluzzo, D., Malone, S., Vidale, J.E., Sweet, J.R., Wech, A.G., 2009. Cascadia tremor located near plate interface constrained by $S$ minus $P$ wave times. Science 323, 620-623.

Le Roux, V., Tommasi, A., Vauchez, A., 2008. Feedback between melt percolation and deformation in an exhumed lithosphere-asthenosphere boundary. Earth Planet. Sci. Lett. 274, 401-413.

López Sánchez-Vizcaíno, V., 1994. Evolución petrológica y geoquímica de las rocas carbonáticas en el área de Macael-Cóbdar, Complejo Nevado-Filábride, SE España. $\mathrm{PhD}$ Thesis, University of Granada.

López Sánchez-Vizcaíno, V., Gómez-Pugnaire, M.T., Garrido, C.J., Padrón-Navarta, J.A., Mellini, M., 2009. Breakdown mechanisms of titanclinohumite in antigorite serpentinite (Cerro del Almirez massif, S. Spain): a petrological and TEM study. Lithos 107, 216-226.

López Sánchez-Vizcaíno, V., Rubatto, D., Gómez-Pugnaire, M.T Trommsdorff, V. Müntener, O., 2001. Middle Miocene high-pressure metamorphism and fast exhumation of the Nevado-Filabride Complex, SE Spain. Terra Nova 13, 327-332.

López Sánchez-Vizcaíno, V., Trommsdorff, V., Gómez-Pugnaire, M.T., Garrido, C.J., Müntener, O., Connolly, J.A.D., 2005. Petrology of titanian clinohumite and olivine at the high-pressure breakdown of antigorite serpentinite to chlorite harzburgite (Almirez Massif, S. Spain). Contrib. Mineral. Petrol. 149, 627-646.

Lund, M.G., Austrheim, H., 2003. High-pressure metamorphism and deep-crustal seismicity: evidence from contemporaneous formation of pseudotachylytes and eclogite facies coronas. Tectonophysics 372, 59-83.

Mackwell, S.J., Kohlstedt, D.L., Paterson, M.S., 1985. The role of water in the deformation of olivine single crystals. J. Geophys. Res. 90, 11319-11333.

Mainprice, D., 1990. A FORTRAN program to calculate seismic anisotropy from the lattice preferred orientation of minerals. Comput. Geosci. 16, 385-393.

Malaspina, N., Hermann, J., Scambelluri, M., 2009. Fluid/mineral interaction in UHP garnet peridotite. Lithos 107, 38-52.

Manning, C.E., 1994a. Fractal clustering of metamorphic veins. Geology 22, 335-338.

Manning, C.E., 1994b. The solubility of quartz in $\mathrm{H}_{2} \mathrm{O}$ in the lower crust and upper mantle. Geochim. Cosmochim. Acta 58, 4831-4839.

Martínez-Martínez, J.M., Soto, J.I., Balanya, J.C., 2002. Orthogonal folding of extensional detachments: structure and origin of the Sierra Nevada elongated dome (Betics, SE Spain). Tectonics 21, 1012. doi:10.1029/2001TC001283.

McInnes, B.I.A., Gregoire, M., Binns, R.A., Herzig, P.M., Hannington, M.D., 2001. Hydrous metasomatism of oceanic sub-arc mantle, Lihir, Papua New Guinea: petrology and geochemistry of fluid-metasomatised mantle wedge xenoliths. Earth Planet. Sci. Lett. 188, 169-183.

Mei, S., Bai, W., Hiraga, T., Kohlstedt, D.L., 2002. Influence of melt on the creep behavior of olivine-basalt aggregates under hydrous conditions. Earth Planet. Sci. Lett. 201, 491-507.

Michot, G., Weil, B., George, A., 1984. In situ observation by synchrotron X-ray topography of the evolution with temperature of fluid inclusions in synthetic quartz. J. Cryst. Growth 69, 627-630.

Miller, S.A., van der Zee, W., Olgaard, D.L., Connolly, J.A.D., 2003. A fluid-pressure feedback model of dehydration reactions: experiments, modelling, and application to subduction zones. Tectonophysics 370, 241-251.

Nestola, F., Angel, R., Zhao, J.., Garrido, C., Sánchez-Vizcaíno, V., Capitani, G., Mellini, M., 2010. Antigorite equation of state and anomalous softening at $6 \mathrm{GPa}$ : an in situ single-crystal X-ray diffraction study. Contributions to Mineralogy and Petrology 160 (1), 33-43.

Nishiyama, T., 1989. Kinetics of hydrofracturing and metamorphic veining. Geology 17, 1068-1071.

Obara, K., 2002. Nonvolcanic deep tremor associated with subduction in southwest Japan. Science 296, 1679-1681.

Padrón-Navarta, J.A., Hermann, J., Garrido, C.J., Sánchez-Vizcaíno, V., Gómez-Pugnaire, M.T. 2010. An experimental investigation of antigorite dehydration in natural silica-enriched serpentinite. Contrib. Mineral. Petrol. 159, 25-42.

Padrón-Navarta, J.A., López Sánchez-Vizcaíno, V., Garrido, C.J., Gómez-Pugnaire, M.T., Jabaloy, A., Capitani, G., Mellini, M., 2008. Highly ordered antigorite from Cerro del Almirez HP-HT serpentinites, SE Spain. Contrib. Mineral. Petrol. 156, 679-688.

Peacock, S.M., 2001. Are the lower planes of double seismic zones caused by serpentine dehydration in subducting oceanic mantle? Geology 29, 299-302. 
Pennacchioni, G., 1996. Progressive eclogitization under fluid-present conditions of pre-Alpine mafic granulites in the Austroalpine Mt Emilius Klippe (Italian Western Alps). J. Struct. Geol. 18, 549-561.

Perrillat, J.P., Daniel, I., Koga, K.T., Reynard, B., Cardon, H., Crichton, W.A., 2005. Kinetics of antigorite dehydration: a real-time X-ray diffraction study. Earth Planet. Sci. Lett. 236, 899-913.

Raleigh, C.B., Paterson, M.S., 1965. Experimental deformation of serpentinite and its tectonic implications. J. Geophys. Res. 70, 3965-3985.

Rogers, G., Dragert, H., 2003. Episodic tremor and slip on the Cascadia subduction zone: the chatter of silent slip. Science 300, 1942-1943.

Rosenberg, C.L., Handy, M.R., 2000. Syntectonic melt pathways during simple shearing of a partially molten rock analogue (Norcamphor-Benzamide). J. Geophys. Res. Solid Earth 105, 3135-3149.

Ruiz Cruz, M.D., Puga, E., Nieto, J.M., 1999. Silicate and oxide exsolution in pseudospinifex olivine from metaultramafic rocks of the Betic Ophiolitic Association: a TEM study. Am. Miner. 84, 1915-1924.

Scambelluri, M., Bottazzi, P., Trommsdorff, V., Vannucci, R., Hermann, J., GómezPugnaire, M.T., López Sánchez-Vizcaíno, V.L.S., 2001. Incompatible element-rich fluids released by antigorite breakdown in deeply subducted mantle. Earth Planet. Sci. Lett. 192, 457-470.

Scambelluri, M., Hoogerduijn Strating, E.H., Piccardo, G.B., Vissers, R.L.M., Rampone, E., 1991. Alpine olivine- and titanian clinohumite-bearing assemblages in the ErroTobbio peridotite (Voltri Massif, NW Italy). J. Metamorph. Geol. 9, 79-91.

Scambelluri, M., Muntener, O., Hermann, J., Piccardo, G.B., Trommsdorff, V., 1995. Subduction of water into the mantle - history of an alpine peridotite. Geology 23, 459-462.

Scambelluri, M., Philippot, P., 2001. Deep fluids in subduction zones. Lithos 55, 213-227.

Schmidt, M.W., Poli, S., 1998. Experimentally based water budgets for dehydrating slabs and consequences for arc magma generation. Earth Planet. Sci. Lett. 163, 361-379.

Schneider, M.E., Eggler, D.H., 1986. Fluids in equilibrium with peridotite minerals: implications for mantle metasomatism. Geochim. Cosmochim. Acta 50, 711-724.

Schönbächer, M., Die Hochdruckmetamorphose der Ultramafika und der angrenzenden Nebengesteine am Cerro de Almirez, Sierra Nevada, Südspanien. Unpublished Diplomarbeit, ETH Zürich, 1999, p. 113.

Seno, T., Yamasaki, T., 2003. Low-frequency tremors, intraslab and interplate earthquakes in Southwest Japan-from a viewpoint of slab dehydration. Geophys. Res. Lett. 30, 2171-2175.

Shelly, D.R., Beroza, G.C., Ide, S., Nakamula, S., 2006. Low-frequency earthquakes in Shikoku, Japan, and their relationship to episodic tremor and slip. Nature 442, 188-191.

Soustelle, V., Tommasi, A., Demouchy, S., Ionov, D., 2010. Deformation and fluid-rock interactions in the supra-subduction mantle: microstructures and water contents in peridotite xenoliths from the Avacha Volcano, Kamchatka. J. Petrol. 51, 363-394.

Stevenson, D.J., 1989. Spontaneous small-scale melt segregation in partial melts undergoing deformation. Geophys. Res. Lett. 16, 1067-1070.
Strating, E.H.H., Vissers, R.L.M., 1991. Dehydration-induced fracturing of eclogite-facies peridotites: implications for the mechanical behaviour of subducting oceanic lithosphere. Tectonophysics 200, 187-198.

Takei, Y., 2005. Deformation-induced grain boundary wetting and its effects on the acoustic and rheological properties of partially molten rock analogue. J. Geophys. Res. 110, B12203.

Tenthorey, E., Cox, S.F., 2003. Reaction-enhanced permeability during serpentinite dehydration. Geology 31, 921-924.

Tenthorey, E., Hermann, J., 2004. Composition of fluids during serpentinite breakdown in subduction zones: evidence for limited boron mobility. Geology 32, 865-868.

Tommasi, A., Godard, M., Coromina, G., Dautria, J.M., Barsczus, H., 2004. Seismic anisotropy and compositionally induced velocity anomalies in the lithosphere above mantle plumes: a petrological and microstructural study of mantle xenoliths from French Polynesia. Earth Planet. Sci. Lett. 227, 539-556.

Tommasi, A., Mainprice, D., Canova, G., Chastel, Y., 2000. Viscoplastic self-consistent and equilibrium-based modeling of olivine lattice preferred orientations: Implications for the upper mantle seismic anisotropy. J. Geophys. Res. Solid Earth 105, 7893-7908.

Tommasi, A., Vauchez, A., Godard, M., Belley, F., 2006. Deformation and melt transport in a highly depleted peridotite massif from the Canadian Cordillera: Implications to seismic anisotropy above subduction zones. Earth Planet. Sci. Lett. 252, 245-259.

Tommasi, A., Vauchez, A., Ionov, D.A., 2008. Deformation, static recrystallization, and reactive melt transport in shallow subcontinental mantle xenoliths (Tok Cenozoic volcanic field, SE Siberia). Earth Planet. Sci. Lett. 272, 65-77.

Toriumi, M., Hara, E., 1995. Crack geometries and deformation by the crack-sea mechanism in the Sambagawa metamorphic belt. Tectonophysics 245, 249-261.

Trommsdorff, V., López Sánchez-Vizcaíno, V., Gómez-Pugnaire, M.T., Müntener, O 1998. High pressure breakdown of antigorite to spinifex-textured olivine and orthopyroxene, SE Spain. Contrib. Mineral. Petrol. 132, 139-148.

Ulmer, P., Trommsdorff, V., 1995. Serpentine stability to mantle depths and subductionrelated magmatism. Science $268,858-861$.

Urai, J.L., Feenstra, A., 2001. Weakening associated with the diaspore-corundum dehydration reaction in metabauxites: an example from Naxos (Greece). J. Struct. Geol. 23, 941-950.

Vauchez, A., Garrido, C.J., 2001. Seismic properties of an asthenospherized lithospheric mantle: constraints from lattice preferred orientations in peridotite from the Ronda massif. Earth and Planetary Science Letters 192 (2), 235-249.

Vrijmoed, J.C., Smith, D.C., Van Roermund, H.L.M., 2008. Raman confirmation of microdiamond in the Svartberget Fe-Ti type garnet peridotite, Western Gneiss Region, Western Norway. Terra Nova 20, 295-301.

Vrijmoed, J.C., Van Roermund, H.L.M., Davis, G.R., 2006. Evidence for diamond-grade ultra-high pressure metamorphism and fluid interaction in the Svartberget Fe-Ti garnet peridotite-websterite body, Western Gneiss Region, Norway. Mineral. Petrol. 88, 381-405.

Watt, G.R., Oliver, N.H.S., Griffin, B.J., 2000. Evidence for reaction-induced microfracturing in granulite facies migmatites. Geology 28, 327-330.

Wilshire, H.G., Kirby, S.H., 1989. Dikes, joints, and faults in the upper mantle Tectonophysics 161, 23-31. 